\title{
Shear Strength Expression for Partially Grouted Masonry Walls
}

\author{
M. Bolhassani ${ }^{1}$, A.A. Hamid ${ }^{2}$, C. Johnson ${ }^{3}$, A. Schultz ${ }^{4}$
}

Abstract: The majority of reinforced masonry constructions in the mid-western and eastern parts of the United States are partially grouted. Previous studies on partially grouted walls have shown that design provisions of the masonry standard joint committee overestimate the shear capacity of such walls. As a result of these studies, masonry standard joint committee has introduced a reduction factor in its newest version in order to overcome this problem. At 2016, the masonry standard joint committee was changed to building code requirements and specifications for masonry structures. The first part of the paper is devoted to this issue by comparing the shear strength of 42 full-scale partially grouted wall tests available in the literature with the current building code requirements and specifications for masonry structures' shear strength expression. Results indicated that the current shear strength expression can accurately predict the shear strength of partially grouted walls with grouted cells spaced to a maximum of $1.2 \mathrm{~m}$ because it was developed based on test results of fully grouted walls. Unfortunately, implementing this factor has not solved the fundamental problem of the code shear strength expression for those walls with grouted cells spaced higher than $1.2 \mathrm{~m}$ (ordinary reinforced masonry). The over-estimation can be traced to the existence of insufficient length of horizontal reinforcement (steel

1. Ph.D., Department of Civil Architectural and Environmental Engineering, Drexel University, Philadelphia, PA, mb3238@drexel.edu.

2. Professor, Department of Civil, Architectural and Environmental Engineering, Drexel University, Philadelphia, PA, hamidaa@drexel.edu.

3. Ph.D. candidate, Department of Civil, Environmental, and Geo-Engineering, University of Minnesota, Minneapolis, MN, joh04739@umn.edu.

4. Professor, Department of Civil, Environmental, and Geo-Engineering, University of Minnesota, Minneapolis, MN, schul088@umn.edu. 
1 effectiveness), and the assumption of linearly varying flexural strains, which the ungrouted

2 portions of the partially grouted wall have proven unable to carry. The goal of the current

3 study is to investigate a new, more realistic approach to the shear mechanism of ordinary

4 reinforced masonry partially grouted walls through adopting modified infilled wall model

5 as opposed to the monolithic wall model that already underpins the problem with the

6 current shear strength expression. A new expression, therefore, was developed for

7 ordinary reinforced masonry partially grouted walls based on modified infilled-frame

8 mechanism. The shear strength predicted by the proposed model was in a good agreement

$9 \quad$ with available test data including walls tested by authors.

10 Keywords: Partially grouted; Masonry wall; Masonry standard joint committee; Infilled-

11 frame.

\section{1. Introduction}

Most of the shear expressions available for reinforced masonry (RM) walls are statistical-based and no analytical equation has been adopted for these types of walls. This is mainly due to the complexity of the shear mechanism in RM walls. Practically, the shear

17 strength of RM walls has been calculated by the summation of three components: masonry 18 contribution, friction due to axial compression stress, and shear reinforcement contribution. The first expression was developed almost three decades ago by [1]. Various other shear expressions have also been reported in literatures including; [2-13], some of

21 them will be discussed here. While many parameters were investigated in these studies,

22 accuracy of the reported expressions, especially in the case of partially grouted (PG) walls, 23 is questioned. 

from testing completed as part of [14]. These assemblages tested were both traditional

3 flexural walls, subjected to double curvature, known as piers. The shear strength formula in 4 [13] is largely based on experimental data obtained from fully-grouted (FG) reinforced 5 masonry walls and piers. A review and comparison of different shear strength formulas reported in the literature were provided in [10]. They explained the derivation of the shear

7 formula adopted in [8] by evaluating the shear expression with data only obtained from FG 8 walls.

9 17 ORM PG walls.

In this study, we proceed to evaluate the shear expression of [13] based on the compiled database of full-scale PG masonry walls. Expressions and discussions existing in literature along with results of the current survey show that introducing new parameters and constants have not solved the inaccuracy of the shear expression for PG walls with grouted cells spaced higher than $1.2 \mathrm{~m}$ classified as ordinary reinforced masonry walls (ORM). Therefore, this issue needs to be viewed from a new perspective separate from introducing arbitrary factors into the FG shear expression, due to the different behavior of

The mechanical behavior of PG walls is more similar to confined masonry and masonry-infilled frames than FG masonry. However, concrete elements of these two systems have more reinforcement than grouted masonry elements in PG walls, where a single bar is placed in the middle of a grouted cell. Vertical grouted cells in PG walls are highly vulnerable to shear failure [15 and 16]. This vulnerability is primarily attributed to 
1 the initiation and propagation of horizontal shear cracks along the bed joints from the

2 hollow masonry panels (weak elements) into the vertically reinforced grouted cells.

3 Regions around the intersection of bond beams and vertically grouted cells are especially

4 susceptible to damage. This is due to interaction between the grouted masonry elements

5 and ungrouted masonry panels near the intersections. This behavior observed in the PG

6 walls is very similar to the strut mechanism developed in masonry infill in infilled-frame

7 structures. A new expression, therefore, was developed for PG walls based on infilled-

8 frame mechanism. The development of the new formula was additionally developed with

9 refined finite element models developed by authors [17 and 18]. A parametric study was conducted considering different spacing of horizontal and vertical reinforced cells, axial

11 compressive loads, masonry compressive strength, and area of steel. Finally, the proposed

12 expression was verified with experimental results of tested walls by authors [18-20] in

13 addition to 42 full-scale PG wall tests available in the literature [10, 15, 21-28].

\subsection{Available reinforced masonry shear strength expressions}

There are almost 10 different shear equations available in the literature for

17 reinforced masonry walls. It should e mentioned that these design provisions and statistical equations are different form each other. The number of contributions to the final

19 shear strength is different and this confirms that the approach used to build the analytical equations/design is different. Even if the coefficients of equations are calibrated through

21 experimental fitting or statistical adjustment. However, the common fact about the most of

22 them is that they are developed solely based on the results of fully grouted specimens. The

23 first shear expression for RM shear walls was developed by [1] to predict the in-plane 
1 shear strength based on testing nearly 60 concrete and 30 brick masonry shear walls. This expression was proposed based on regression analysis of test results in the conventional

3 form of three terms: the contribution of the shear strength of masonry, axial stress, and 4 shear reinforcement, as can be seen in Eq. 1. Factors $k_{u}$ (factor concerning the type of 5 grouting) and $\gamma$ (factor concerning the action to confine grout) were considered 0.64 and 0.6 for PG walls, respectively.

$7 \quad V_{n}=\left[k_{u} k_{p}\left(\frac{0.76}{(h / d)+0.7}+0.012\right) \sqrt{f 0_{m}}+0.2 \sigma_{n}+0.18 \gamma \delta \sqrt{\left.\rho_{h} f_{y h} f\right]_{m}}\right] \times(0.875 t d)$

9

$$
0
$$

Another shear expression was proposed by [2] for concrete RM walls, employing regression analysis of the shear strength of 22 FG shear walls tests (Eq. 2). All vertical reinforcement was considered effective due to the dowel action. Although, this expression was developed based solely on FG wall test results, it was directly applied for predicting the shear strength of PG masonry as well. In this expression, the contribution of the bottom and top transverse reinforcement were neglected because of insufficient development length caused by diagonal cracks. Additionally, a distinct term for the effect of axial stress was not considered and instead is included with the masonry term.

$$
V_{n}=\left(0.166+0.0217 \rho_{\mathrm{v}} \mathrm{f}_{\mathrm{yv}}\right) \sqrt{\mathrm{f}_{\mathrm{m}}^{\square}} \mathrm{A}_{\mathrm{n}}+\left(0.0217 \sigma_{\mathrm{n}} \mathrm{A}_{\mathrm{n}}\right) \sqrt{\mathrm{f}_{\mathrm{m}}^{\natural}}+\left(\frac{\mathrm{L}-2 \mathrm{~d}^{\square}}{\mathrm{s}_{\mathrm{h}}}-1\right) \mathrm{A}_{\mathrm{h}} \mathrm{f}_{\mathrm{yh}}
$$


1 based only on test results conducted in 1980 or earlier. As can be seen from the expression,

2 the effect of axial compressive stress was included in the $V_{m}$ term $\left(V_{m}=0.1 f_{m}^{\prime}+\sigma_{n}\right)$. The

3 effect of vertical reinforcement was not considered here and full contribution of the

4 horizontal reinforcement was included without any limitation on their locations in the wall.

$5 \quad V_{n}=\mathrm{V}_{\mathrm{m}} \mathrm{b}_{\mathrm{w}} \mathrm{d}+A_{h} f_{y h} \mathrm{~d} / \mathrm{s}_{h}$

6

7

8

9

10

11

12

13

14

15

16 17 walls.

$18 V_{n}=C_{a p} K A_{n} \sqrt{f_{m}^{\text {] }}}+0.25 \sigma_{n} A_{n}+0.5 A_{h} f_{y h} d / s_{h}$

[4] developed an expression (Eq. 4) for reinforced masonry shear strength utilizing the test results in [1, 2 and 29]. The effect of dowel action of vertical reinforcement was neglected in this expression. Although the shear strength of masonry is affected by the type of masonry and effect of inelastic deformation of masonry shear strength, previous studies overlooked these two parameters in deriving their expressions. However, in the first part of Eq. 3 a reduction factor $\left(C_{a p}\right)$ was introduced based on wall ductility for considering the degradation of masonry shear strength in the inelastic response. Additionally, in this expression another coefficient factor $(K)$ was introduced for different types of masonry employed in the wall construction. Again, no specific parameter was defined for PG masonry shear walls and the same shear mechanism was considered for both FG and PG

[5] adopted an expression similar to Eq. 4. The ductility factor was expressed in

21 terms of the wall aspect ratio $\left(\frac{M}{V L}\right)$ as shown in Eq. 5. This shear expression took one step

22 back in considering the inelastic behavior of masonry and just relied on the wall aspect 
1 ratio. The effect of dowel action and vertical reinforcement were neglected in the 2 expression and no clear distinction was defined for PG walls.

$3 \quad V_{n}=0.083\left[4.0-1.75 \frac{M}{V L}\right] A_{n} \sqrt{f_{m}^{\square}}+0.25 \sigma_{n} A_{n}+0.5 A_{h} f_{y h} d_{v} / s_{h}$

4

5

6

7

8

$9 \quad V_{n}=0.083\left[2.8-1.6\left(\frac{h_{e}}{d_{v}}\right)\right] A_{n} \sqrt{f_{m}^{0}}+A_{s h} f_{y h}$

In 2007, [10] introduced modification factors to the [3] equation, creating the new

12 shear expression [8]. This expression (Eq. 7) also did not provide any special consideration

13 for PG walls.

$14 V_{n}=\left[0.022 \rho_{\mathrm{v}} \mathrm{f}_{\mathrm{yv}}+0.084\left(4.0-1.75 \frac{h_{e}}{l_{w}}\right)\right]\left(1-\frac{\mu-1.25}{2.75}\right) A_{n} \sqrt{f_{m}^{\sqrt{0}}}+(0.9 \tan \alpha) \mathrm{P}^{*}+A_{h} f_{y h} d_{e} / s_{h}$

17 developed by [5] for PG walls, see Eq. 8. The reduction factor is associated with the results of PG and FG walls reported by [16 and 30], respectively. In each category, the ratio of the actual shear strength over the shear strength of [13] estimation (called TMS (2016) expression herein) were calculated. Ultimately, the reduction factor was extracted by 21 dividing the mean results of PG walls to FG walls. 
$1 \quad V_{n}=\gamma_{g}\left(0.083\left[4.0-1.75 \frac{M}{V L}\right] A_{n} \sqrt{f_{m}^{\square}}+0.25 \sigma_{n} A_{n}+0.5 A_{h} f_{y h} d_{v} / s_{h}\right)$

3 $\alpha$ and $\beta$ modification factors, as shown in Eq. 9, were introduced by [31] in order to

5 improve the TMS (2016) expression. Factor $\alpha$ was introduced to include the effect of

6 reinforcement spacing and the wall aspect ratio. It was concluded in [31] that strain in the

7 horizontal reinforcing bars reduced as horizontal reinforcement ratio increased. Therefore,

8 factor $\beta$ was introduced to account for this reduction in the steel efficiency.

$9 \quad V_{n}=\alpha\left[4.0-1.75 \frac{M}{V L}\right] A_{n} \sqrt{f_{m}^{\square}}+0.25 \sigma_{n} A_{n}+\beta\left(0.5 A_{s h} f_{y h} d_{v} / s_{h}\right)$

11 2. Database

Not many studies have been carried out on the seismic performance of PG walls.

13 Among those available, research focusing on full scale tests of PG walls are selected here 14 and demonstrated in Table 1 . These studies are explained to some extent in this section. 
Table 1 Partially grouted wall database

\begin{tabular}{|c|c|c|c|c|c|c|c|c|c|c|c|}
\hline \multirow{2}{*}{ Name } & \multirow{2}{*}{$\begin{array}{c}\text { Height } \\
\mathrm{m} \\
\end{array}$} & \multirow{2}{*}{$\begin{array}{c}\text { Length } \\
\mathrm{m}\end{array}$} & \multirow{2}{*}{$\begin{array}{c}\text { Thickness } \\
\mathrm{mm}\end{array}$} & \multirow{2}{*}{ Boundary } & \multicolumn{3}{|c|}{ Reinforcement } & \multicolumn{2}{|c|}{ Grout Spacing m } & \multirow{2}{*}{$\begin{array}{c}\text { Prism } \\
\text { Strength (f'm) } \\
\text { MPa }\end{array}$} & \multirow{2}{*}{$\begin{array}{c}\text { Axial Load } \\
\text { kN }\end{array}$} \\
\hline & & & & & Vertical & Shear & $\begin{array}{c}\text { Joint- } \\
\text { Reinforcement } \\
\end{array}$ & Horizontal & Vertical & & \\
\hline \multirow{4}{*}{$\begin{array}{c}\text { Chen et al. (1978) } \\
\text { [20] }\end{array}$} & \multirow{4}{*}{1.4} & \multirow{4}{*}{1.2} & \multirow{4}{*}{194} & \multirow{4}{*}{ Fixed } & - & - & \multirow[t]{4}{*}{ 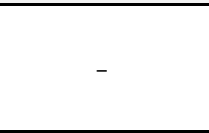 } & 1.4 & \multirow{4}{*}{0.9} & \multirow{4}{*}{10.8} & 188 \\
\hline & & & & & 2D16 & 1D16 & & 0.7 & & & 134 \\
\hline & & & & & 2D25 & - & & 1.4 & & & 130 \\
\hline & & & & & 2D25 & 2D16 & & 0.5 & & & 139 \\
\hline \multirow{8}{*}{$\begin{array}{c}\text { Yancey\& } \\
\text { Scribner(1989) } \\
\text { [23] }\end{array}$} & \multirow{8}{*}{1.4} & \multirow{8}{*}{1.2} & \multirow{8}{*}{194} & \multirow{8}{*}{ Fixed } & & - & 9-ga. ladder & 1.4 & & & 321 \\
\hline & & & & & & - & 9-ga. ladder & 1.4 & & & 268 \\
\hline & & & & & & 2D13 & - & 0.7 & & & 368 \\
\hline & & & & & & 3D16 & - & 0.7 & & & 275 \\
\hline & & & & & - & 1D16 & - & 0.5 & 1 & 21.1 & 294 \\
\hline & & & & & & 1D10 & 9-ga. ladder & 0.7 & & & 346 \\
\hline & & & & & & 2D13, 1D16 & 9-ga. ladder 1D16 & 0.7 & & & 395 \\
\hline & & & & & & 1D16 & - & 0.5 & & & 310 \\
\hline & & 2.6 & 90 & & 4D10 & 1D10 & & & & & \\
\hline & & 1.8 & 140 & & 3D13 & 1D16 & & & & & \\
\hline & & 2.6 & 140 & & 4D13 & 1D13 & & & & & \\
\hline Brammer (1995) & 2.4 & 4.2 & 140 & Cantilever & 6D13 & 1D16 & - & 2 & 0.8 & 16.3 & 0 \\
\hline & & 1.8 & 190 & & 3D13 & 1D16 & & & & & \\
\hline & & 2.6 & 190 & & 4D13 & 1D16 & & & & & \\
\hline & & 4.2 & 190 & & 6D13 & 1D16 & & & & & \\
\hline & & 2.8 & & & & 2D10 & & & 2.7 & & 267 \\
\hline & & 2.1 & & & & 2D10 & & & 1.9 & & 191 \\
\hline Schultz (1996) & & 1.4 & & & & 2D10 & & & 1.3 & & 133 \\
\hline [14] & 1.4 & 2.8 & 194 & Fixed & 2D19 & 1D13, 1D16 & - & 0.7 & 2.7 & 14.5 & 266 \\
\hline & & 2.1 & & & & 1D13, 1D16 & & & 1.9 & & 177 \\
\hline & & 1.4 & & & & 1D13, 1D16 & & & 1.3 & & 132 \\
\hline $\begin{array}{c}\text { Voon \&Ingham } \\
(2006)[10]\end{array}$ & 1.8 & 1.8 & 140 & Cantilever & $\begin{array}{l}\text { 5D22 } \\
\text { 3D22 }\end{array}$ & - & - & $\begin{array}{l}0.4 \\
0.8\end{array}$ & 1.6 & 18.5 & 0 \\
\hline & & & & Cantilever & & & & & & & 222 \\
\hline Minaie et al. & 26 & 39 & 194 & Cantilever & & & & 12 & 12 & 172 & 222 \\
\hline & 2.6 & 3.9 & 194 & Fixed & 4D19 & 1019 & - & 1.2 & 1.2 & 17.2 & 0 \\
\hline & & & & Fixed & & & & & & & 0 \\
\hline & & & & & $4 \mathrm{D} 19$ & 1D16 & & & 1.2 & & \\
\hline & & & & & 4D19 & 1D16 & & & 1.2 & & \\
\hline Elmapruk (2010) & 16 & 26 & 194 & Cantilever & 4D19 & 1D19 & & 07 & 1.2 & 174 & 494 \\
\hline$[26]$ & 1.0 & 2.0 & 194 & Cantılever & 4D19 & 2D16 & - & 0.7 & 1.2 & 17.4 & 49.4 \\
\hline & & & & & 4D19 & 1D16 & & & 0.8 & & \\
\hline & & & & & 3D13, 2D19 & 1D16 & & & 0.6 & & \\
\hline & & & & & $4 \mathrm{D} 22$ & 1D16 & & & 1.2 & & \\
\hline & & & & & $4 \mathrm{D} 22$ & 1D19 & & & 1.2 & & \\
\hline Nolph\&EIGawady & 2.3 & 2.6 & 194 & Cantilever & $4 \mathrm{D} 22$ & 2D16 & - & 1.1 & 1.2 & 11.3 & 49.3 \\
\hline & & & & & 4D19 & 1D16 & & & 0.8 & & \\
\hline & & & & & 5D16 & 1D16 & & & 0.6 & & \\
\hline
\end{tabular}



of 1.0 were tested by [21]. Although the spacing between vertically grouted cells was held

3 constant, different spacings for bond beams were chosen. Cyclic load pattern and fixed-

4 fixed boundary conditions were used. It was demonstrated that the shear strength of the

5 PG walls were lower than that of FG walls. However, the net ultimate shear stress of the PG

6 piers was $22 \%$ higher than that of FG specimens. All the specimens failed in a shear mode.

7 Additionally, walls with more vertical reinforcement did not show better performance than

8 those containing less. Therefore, the extra amount of flexural reinforcement was

9 redundant, showing no influence on the shear strength of the specimens. This can be 10 attributed to the pier frame action which carried additional axial load. As a result, the 11 existing vertical compression stress on the piers counteracted some parts of the tensile 12 stress that vertical reinforcement was designed to resist. Results of [21] showed that the 13 energy dissipation of all the specimens increased as the drift ratio increased. The amount of 14 reinforcement in both the horizontal and vertical directions appeared to be negligible as 15 well.

Eight PG walls were tested by [24] to determine the effect of varying the amount and distribution of horizontal reinforcement on the shear resistance of PG masonry walls.

19 All of the walls were constructed using only horizontal bed joint reinforcement with no vertical reinforcement as shown in Table 1 . These walls were subjected to reversed cyclic

21 load pattern combined with constant axial compressive stress and all the specimens had 22 fixed-fixed boundary conditions. All the walls exhibited shear mode of failure by presenting 23 cracks propagating along the major diagonals of the panels. It was concluded that small 

.

amount of shear reinforcement were effective in postponing crack initiation by increasing the cracking strength. Observation of [24] showed that the ultimate shear strength of the walls increased as shear reinforcement increased, however not proportionally.

[25] performed quasi static reversed cyclic tests on seven cantilevered PG walls. All the specimens were built with the same height, but different width and length and tested under in-plane lateral load with no axial load present. As anticipated, results showed that all walls but one failed in shear through diagonal tension cracks due to the lack of horizontal reinforcement. The main aim of this research was to evaluate the accuracy of shear strength expression proposed in [4]. It was concluded that these walls have shear strength significantly greater than the code's prediction and the level of conservatism increased as the length of walls increased.

14

[15] tested twelve PG concrete masonry shear walls under in-plane loads. Six of them contained deformed bars as horizontal reinforcement in grouted bond beams and the six other contained bed-joint reinforcement. The specimens were subjected to quasi-static cyclic lateral displacements with fixed-fixed boundary conditions and nearly constant vertical compressive stress. It was concluded that the lateral resisting mechanism for PG reinforced masonry is vastly different from that of FG reinforced masonry. His results showed that as the aspect ratio increased, the ultimate shear stress increased but the stiffness decreased. Cracks that formed between the grouted and ungrouted cells tended to grow and disturb the anchorage region of the horizontal reinforcement where they intersect the vertical cells, thus, increasing the level of horizontal reinforcement slightly 
1 increased the ultimate shear strength but had a negligible effect on stiffness. Because of the

2 limited number of tests, and the scatter of the data that is typical in shear strength tests, no

3 definitive conclusions could be drawn from this study. However, upon investigating the

4 performance of different shear strength formulas, he concluded that a formula developed

5 by [1] best represents the trends observed.

6

7

9

0

21

Thirteen PG concrete masonry walls with and without opening configurations were tested by [32] with varying aspect ratios and reinforcement quantities. The height to length ratios ranged from 0.6 to 3.0. These walls were nominally reinforced and had shear reinforcement only at the top two courses of the walls. All walls exhibited diagonal shear failure due to lack of shear reinforcement. [10] further tested ten walls, only two of which were $\mathrm{PG}$, to investigate the shear strength of concrete masonry and to measure the accuracy of the [8] and [5] expressions. These walls constructed with a range of flexural reinforcement, however, no shear reinforcement or axial load were present. Their observations and test results revealed that the [5] expression can predict the experimental shear strengths of the walls better than the [8] expression. However, both expressions underestimate the shear strength of PG walls significantly because of neglecting the area of grouted cells. strength expression and evaluate the seismic vulnerabilities of PG reinforced masonry shear walls. The walls were tested under reversed displacement control cyclic quasi-static patterns. All the walls were constructed with the same aspect and steel ratios, varying in 
1 boundary conditions and axial load. It was shown that the [11] code's provisions

2 overestimate the shear capacity of PG masonry shear walls by an order of two. Their

3 observation showed that the [11] expression for PG walls became increasingly more

4 unconservative as the spacing of both horizontal and vertical steel increased. Results of this

5 study indicated that the behavior of PG walls is similar to that of infilled frames. They also

6 concluded that frame mechanism caused part of the low shear strength of PG walls due to

7 the loss of coupling between vertical reinforcing steel.

8

[27] tested six full scale PG walls with identical aspect ratios, vertical reinforcement ratio, and level of pre-compressive load. This study was aimed to investigate the effect of spacing of vertical reinforcement on the seismic performance of PG walls. An inverse relationship between the shear strength and spacing of vertical reinforcement was observed. The same ultimate lateral shear stress was reported for the specimens having vertical reinforcement spacing of $610 \mathrm{~mm}$ and $813 \mathrm{~mm}$. Ductile failure mode was observed for the specimen having a vertical reinforcement spacing of $1.2 \mathrm{~m}$ due to the yielding of flexural reinforcement. He also reported that the shear strength decreased and ductility increased as the grout vertical spacing increasing. Increasing the grouted vertical spacing also changed the failure mode of walls from masonry toe crushing to yielding of vertical steel. [27] concluded that the [12] expression is highly unconservative by over-predicting the shear strength of PG walls. 
1 walls with $1.2 \mathrm{~m}$ horizontal spacing between vertical reinforcement because of

2 overestimating the contribution of the horizontal reinforcement. However, it was adequate

3 for walls with spacing between vertical steel less than $0.8 \mathrm{~m}$. The amount and distribution

4 of horizontal and vertical reinforcement was effective for both development of shear

5 strength and crack control. When the spacing of vertical reinforcement was relatively close,

6 less than $1.2 \mathrm{~m}$, they reported that the behavior of PG wall became more similar to FG

7 walls, due to the percentage of grouted cells. As mentioned before, PG walls are designed

8 based on an expression developed for FG walls. Therefore, by changing the hollow space

9 between the horizontal and vertical reinforcement cells from $1.2 \mathrm{~m}$ to $0.8 \mathrm{~m}$ or less, the 10 shear expression became more conservative.

\section{3. Experimental program}

\subsection{PG Walls without openings}

Portland cement lime (PCL) mortar type S according ASTM C270 ingredient proportion, as shown in Table 2 for each mix, with an average 28 days compressive strength of $3 \mathrm{MPa}$ meeting ASTM C109 was used. Coarse grout according to standard specification for grout for masonry ASTM C 476 with an average net compressive strength of 23 MPa meeting ASTM 1019 was used (see Table 2). Grout slump of $250 \mathrm{~mm}$ was used.

\begin{tabular}{lccc}
\hline \multicolumn{1}{c}{ Material } & Code & Mortar, Kg & Grout, Kg \\
\hline Fine Sand & ASTM C 144-11 & 42 & - \\
Coarse Sand & ASTM C 404-11 & - & 29.3 \\
Gravel & ASTM C 404-11 & - & 22.7 \\
Lime & - & 2.4 & - \\
Portland Cement & ASTM C 150-15 & 11 & 11.5 \\
\hline
\end{tabular}



and grout were mixed in-house (see Figure 1). Because of wall height, a forklift was used to 3 carry and pass the material to the masons.
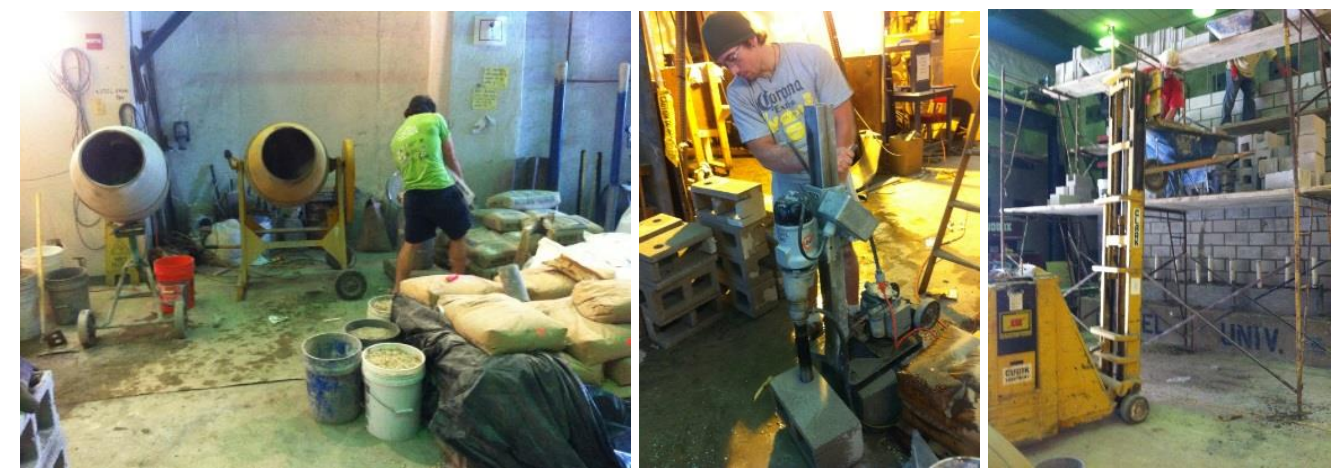

Fig. 1 Grout and mortar preparation, unit cutting and material delivery

Because of the specific shape of the setup, there were some extra works to prepare units at the top bond beam level. Units with side holes were needed for attaching the load beam to the wall. Figure 1 shows the cutting and details of these units. Some of the top course units were perforated and paper tubes placed in their holes in order to prepare them for attaching the loading beams using rods. Vertical reinforcing steel rods were embedded into the foundation using Epoxy Hilty $500 \mathrm{MC}$ with $254 \mathrm{~mm}$ depth as shown in

\section{Fig. 2.}



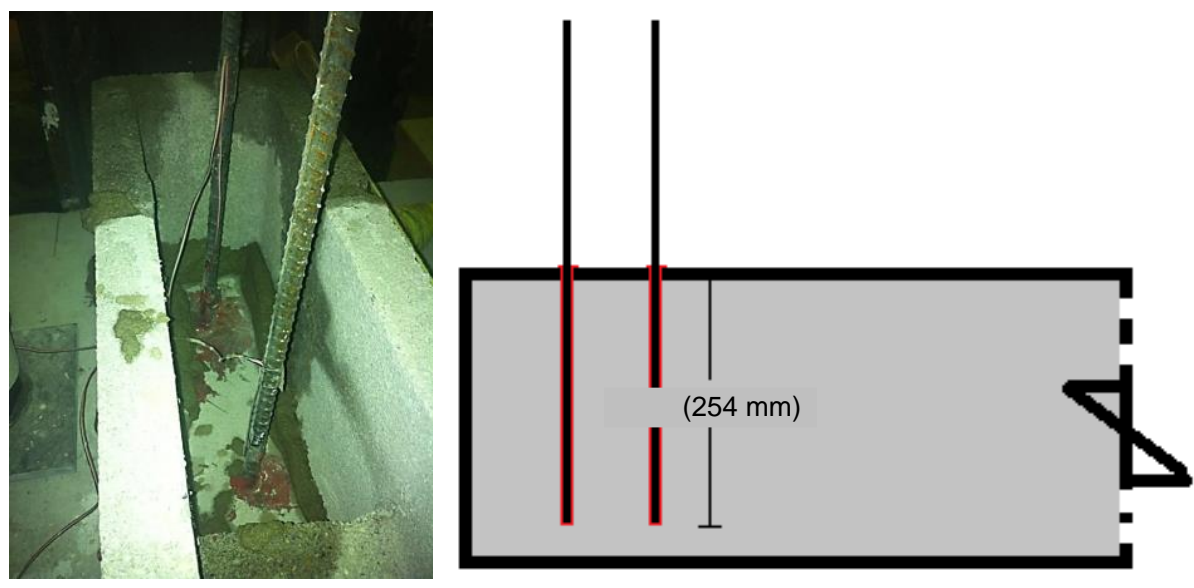

Fig. 2 Epoxy vertical reinforcement into the foundation

Figure 3 shows the pouring and vibrating grout into the cells, also it is representing the wet surface after poring and vibrating the grout into the vertical cells. This wet surface is a proof that grout had enough amount of slump.
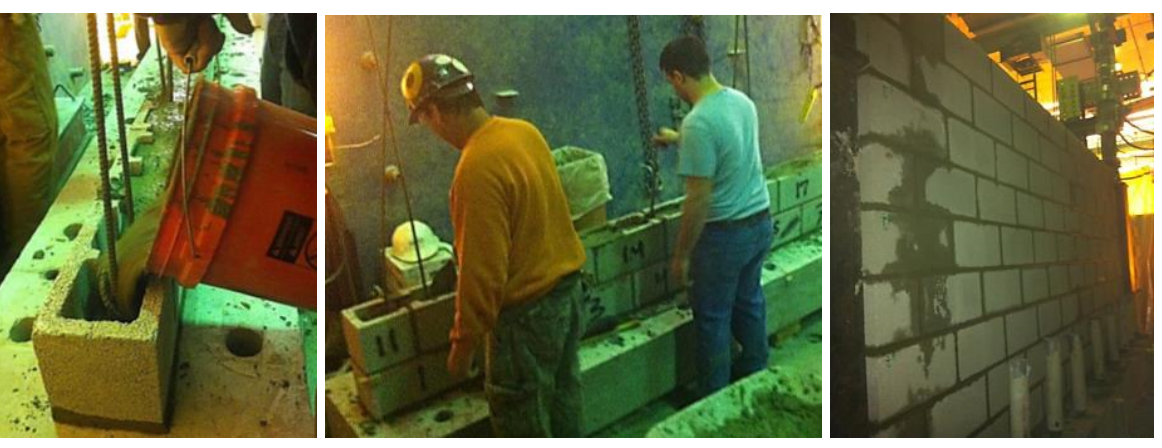

Fig. 3 Pouring grout and vibration, wet surface of grouted column

A horizontal actuator at the top and two vertical actuators at the two sides transferred the horizontal and vertical load, through two stiff channel beams (called loading beam herein) which were post-tensioned to the wall, see Fig. 4. The boundary conditions of the walls were considered as a cantilever with the inflection point at the top of the walls with an aspect ratio of 1.0. The two vertical actuators were programmed to 
1 impose axial compressive stress without any resistance against wall rotation at top (i.e.

2 when the horizontal actuator is pushing the wall, right side actuator arm becomes shorter

3 and left side actuator becomes longer without altering the applied force). To prevent the

4 wall from moving out-of-plane, the test specimen was restrained with hinged out-of-plane

5 supports at the top. Also, two additional courses were built above the target height of the

6 wall to provide enough development length of the vertical bars, and also properly

7 transferring the horizontal load to the wall. This configuration along with the pre-stress

8 loading beam was used to simulate the connection of floor diaphragm to the bearing 9 masonry wall.

The test setup for constructing and testing the masonry walls was designed and

12 fabricated in-house. Based on pre-analysis of the walls, the setup components were 13 designed to carry and transfer $1,335 \mathrm{kN}$ shear force and $445 \mathrm{kN}$ axial loads. The setup 14 included two $2.4 \times 1.2 \times 0.6 \mathrm{~m}$ foundation blocks (called footing herein) next to each other 15 and $4.3 \times 0.9 \times 0.3 \mathrm{~m}$ foundation beam (called concrete beam herein) that was tighted down 16 and post tensioned to the strong floor (see Fig. 4). The setup also included two H shape 17 steel columns under the vertical actuators sitting on foundation blocks, two steel channel as load beam connected to the horizontal and vertical actuators, out-of-plane support and 19 another external long column standing out of setup just to hold the LVDT's (Linear Variable 20 Differential Transformers) sensors to record the horizontal displacement of specimens. 


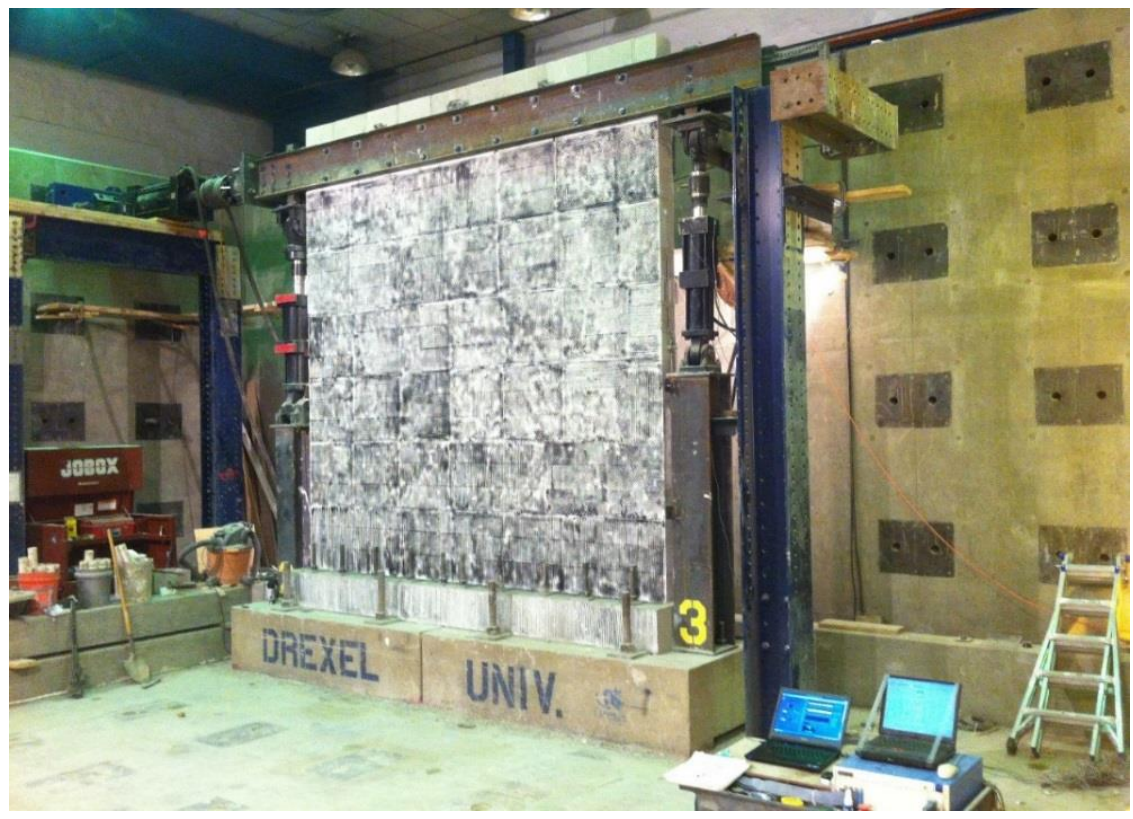

Fig. 4 Test setup

The first wall was built with single horizontal and vertically grouted cells under the conventional design details following [13] provisions. However, in order to investigate the role of the frame on the behavior of PG walls, the second specimen was built with two sideby-side horizontal and vertical grouted cells. The first and second specimens were designated by (single reinforcement) SR and (double reinforcement) DR, respectively. These walls are ordinary reinforced masonry (ORM) based on the [13] provisions only differencing between the number of bars while the steel ratio remains the same. As a result, there are two grouted cells instead of one, in both the beams and cells of the double reinforced specimen. Vertical reinforcement in the SR and DR specimens consisted of 1D19 and 2D13, respectively. Specimens had vertical reinforcement ratio of approximately $0.1 \%$ of the net cross section area. The reinforcement of the first specimen (1D 19) bars spaced at $1.8 \mathrm{~m}$ on center in the vertical and horizontal directions. However, the reinforcement configuration for the second specimen was 2D13 bars in each direction. Fig. 5 shows the detail of these two specimens. Walls were tested with $0.14 \mathrm{MPa}$ of axial stress on the net 
1 area of walls. The summarized experimental shear strength $\left(V_{u}\right)$, and predicted strength using TMS (2016) expression ( $\left.V_{n}\right)$ are shown in Table 3. The expression showed $70 \%$ and $364 \%$ error in predicting the capacity of single and double grouted cells walls, respectively. 4 More details of test set-up and wall configurations can also be found in [18 and 19].

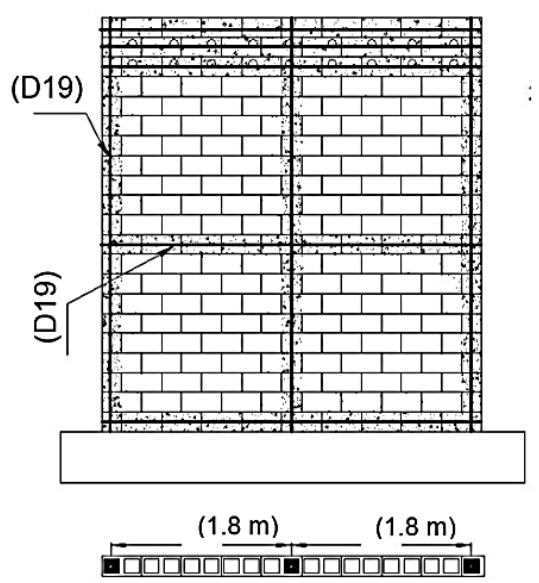

(a) Wall SR

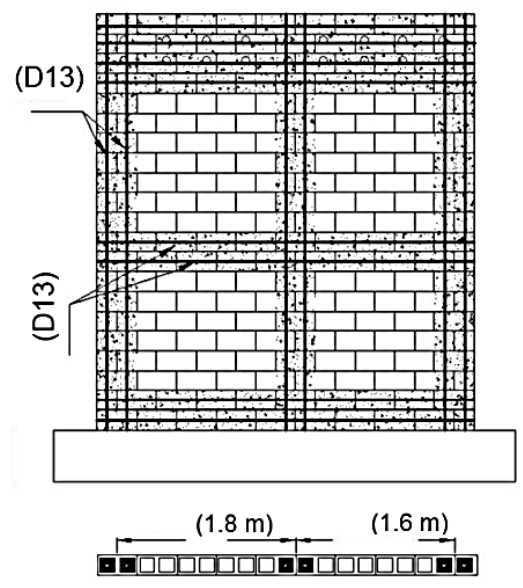

(b) Wall DR

Fig. 5 Reinforcement configurations

\subsection{PG Wall with opening}

One extra SR PG wall with opening (SRO) was built and tested for evaluating the effect of opening on the shear strength expression. Lateral loads were imposed by two actuators attached to loading beams that were anchored into the concrete topping shown in Fig. 6. An external vertical load was applied to the wall by means of four Dywidag posttensioned rods that extended from the foundation to the roof structure. Because load would increase as strain was induced in the rods from drift, a spring was placed between the monitoring load cells and the nut to introduce compliance and keep this load approximately constant. In addition to the externally applied load, the weight of the roof and the loading beams added additional axial stress. The total axial stress on each pier (the two sections of the wall on either side of the opening) was approximately $0.3 \mathrm{MPa}$ to 
1 simulate gravity loads. Load cells were used to monitor the load in the Dywidag post 2 tensioned rods, as well as the actuators.

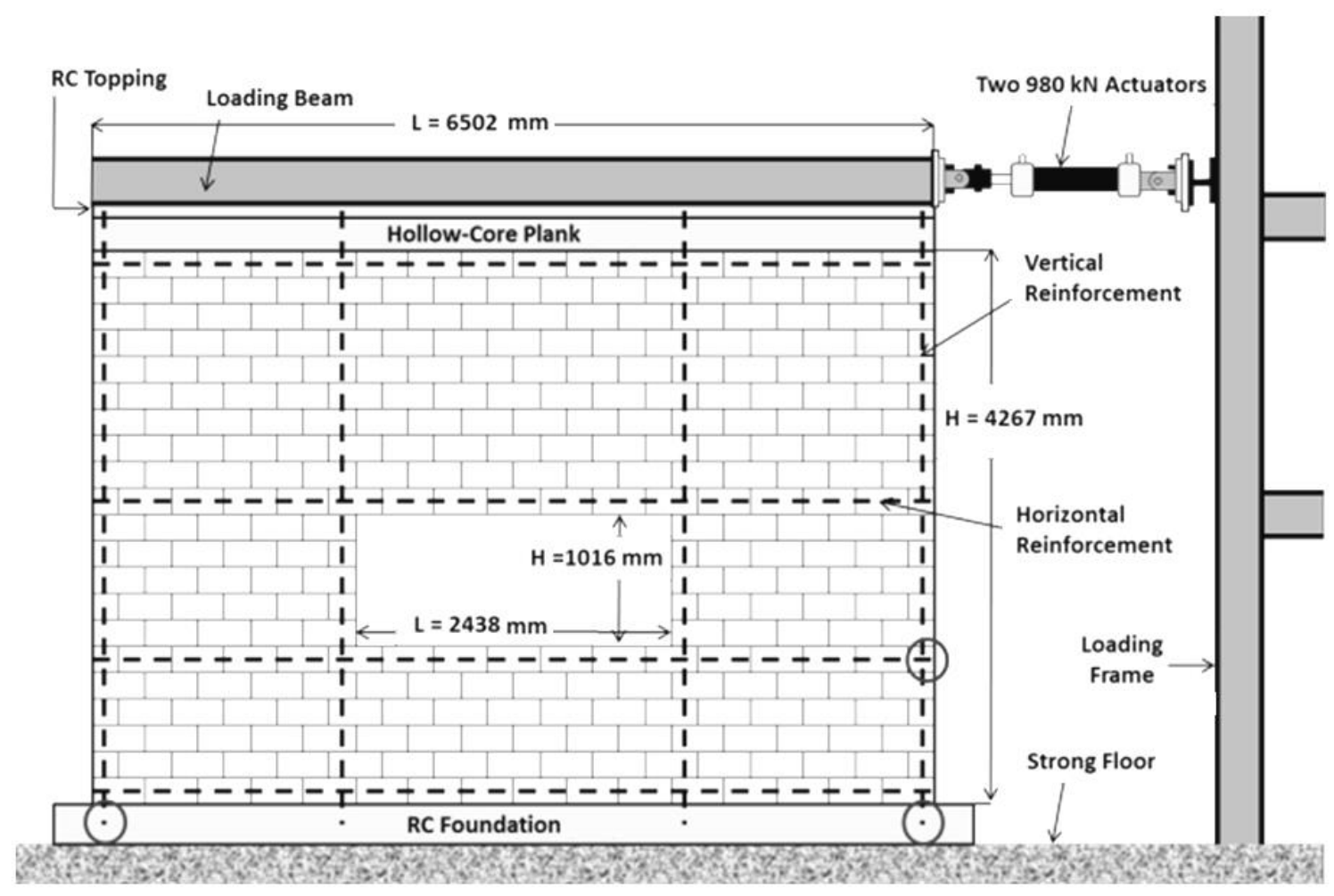

Fig. 6 Test-setup for the wall with opening

The wall experienced the maximum shear force, $V_{u}$, of $273 \mathrm{kN}$ corresponding to the wall drift of $0.29 \%$. The low drift proved that the wall failed in a low ductile shear mechanism (Table 3). The TMS (2016) expression showed a high accuracy in predicting the capacity of this wall. More detail on test results can be found in [33]. 
Table 3 Experimental and predicted shear strength of walls

\begin{tabular}{cccc}
\hline Wall ID. & $\begin{array}{c}\text { Experimental } \mathrm{V}_{\mathrm{u}} \\
\mathrm{kN}\end{array}$ & $\begin{array}{c}\text { Shear Capacity } \mathrm{V}_{\mathrm{n}} \\
\mathrm{kN}\end{array}$ & Failure Mode \\
\hline SR & 168 & 285 & Low ductility shear \\
DR & 221 & 363 & Ductile shear \\
SRO & 273 & 272 & Low ductility shear \\
\hline
\end{tabular}

2

3 4. Evaluation of MSJC's (2013) shear strength expression for PG masonry Reported shear strength of walls tested in the literatures ( $\left.V_{\text {exp }}\right)$ is compared with

5 the shear strength predicted by TMS (2016) expression $\left(V_{n}\right)$ and the final results are

6 plotted in Fig. 7a. Surprisingly, TMS (2016) fails to predict the shear strength of walls in $765 \%$ of cases. Although the TMS (2016) expression cannot exactly predict the shear

8 strength of walls, only $36 \%$ of specimens fell out of the standard deviation of samples $9 \quad(\mathrm{SD}=0.25 \mathrm{kN})$. This overestimation is shown in Figs. $7 \mathrm{a}$ and $7 \mathrm{~b}$ using the lower limit and

10 histogram plot, respectively. It should be mentioned that the upper bound covers the 11 specimens very well and few data appeared out of the standard deviation limit. Hence, it 12 can be concluded that the TMS (2016) expression, even after introducing reduction factor, 13 is still unconservative for many of tested walls and, therefore, need to be revised. 


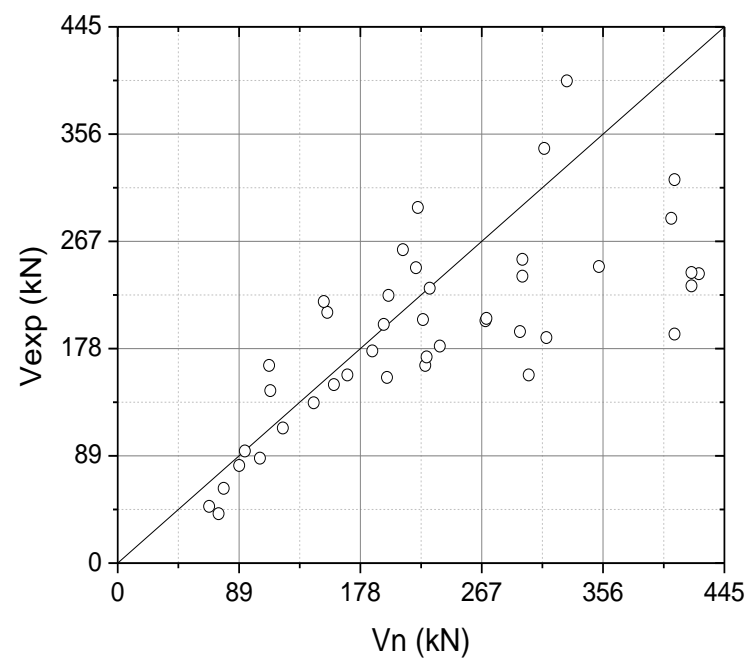

(a) Scattered data

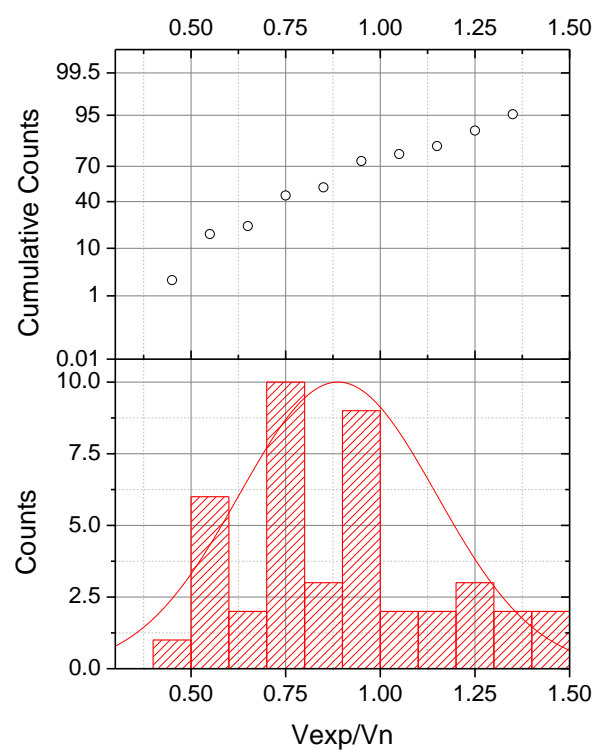

(b) Histogram graph

Fig. 7 MSJC shear strength prediction

3

4

[31] found that grout spacing and horizontal steel effectiveness are two key factors in predicting the shear strength of PG walls. He concluded that increasing the grout spacing and amount of shear reinforcement significantly effect on the over-prediction of the TMS (2016) expression. Consequently, he introduced two new factors to replace the one general reduction factor based on [27, 28 and 34] test results. Although these two mentioned parameters improved the accuracy of the TMS (2016) expression, other parameters, such as wall aspect ratio, masonry compressive strength, axial load and spacing between bond beams still need to be taken into account for an accurate prediction.

To that end, the effect of three terms in the TMS (2016) expression (masonry contribution Vn-A, axial load Vn-B, and shear reinforcement Vn-C) are investigated using available test data. Results showed that TMS (2016) expression is more un-conservative 
1 when masonry contribution term (Vn-A) increases (Fig. 8a). Increasing the axial load has a

2 negligible effect on the over-prediction of shear strength, as shown in Fig. 8b. However,

3 surprisingly, as the shear reinforcement increases the over-prediction of the TMS (2016)

4 expression also increases, which is in agreement with [31] findings (Fig. 8c). By factoring

5 out the net area term from the TMS (2016) expression, overestimation can be related to

6 the following design details: aspect ratio and $f_{m}^{\prime}$, axial stress $\left(\sigma_{n}\right)$, spacing of vertical cells

7 and shear reinforcement amount for masonry contribution, and axial load and shear

8 reinforcement terms. Fig. 9 shows the effect of different parameters on the accuracy of TMS

9 (2016) expression. All of these parameters were plotted as compared with the shear 10 strength ratio by showing the standard deviation.

11

12

13

14

15

16

17 


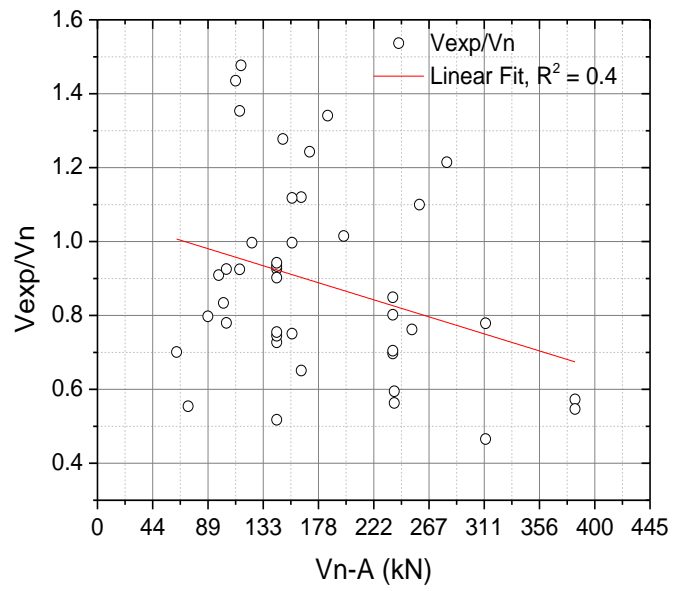

(a) Masonry

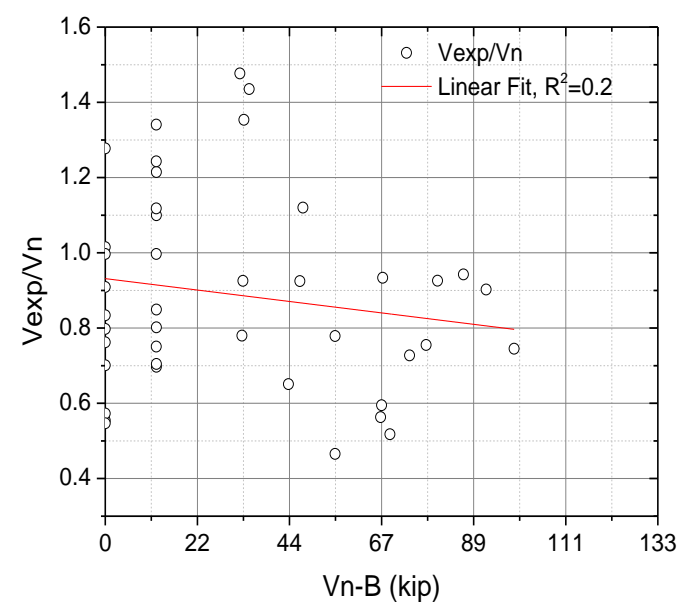

(b) Axial stress

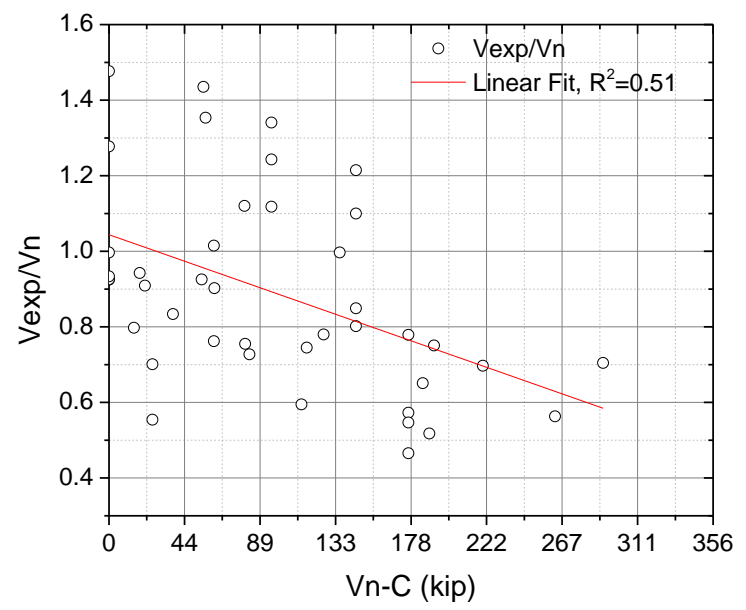

(c) Shear reinforcement

Fig. 8 TMS (2016) expression terms 


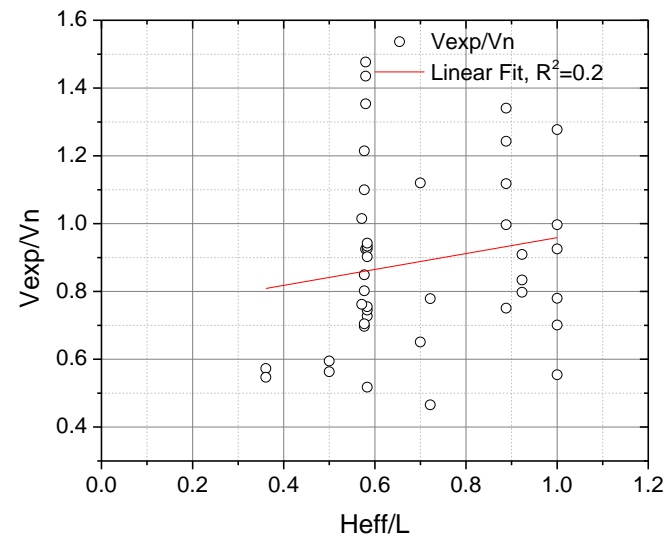

(a) Aspect ratio, $\mathrm{H}_{\text {eff }} / \mathrm{L}$

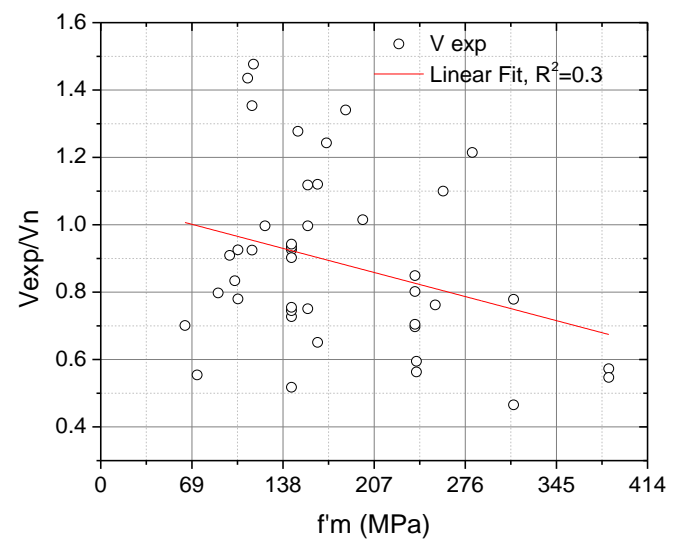

(b) Compressive strength, $\mathrm{f}_{\mathrm{m}}$

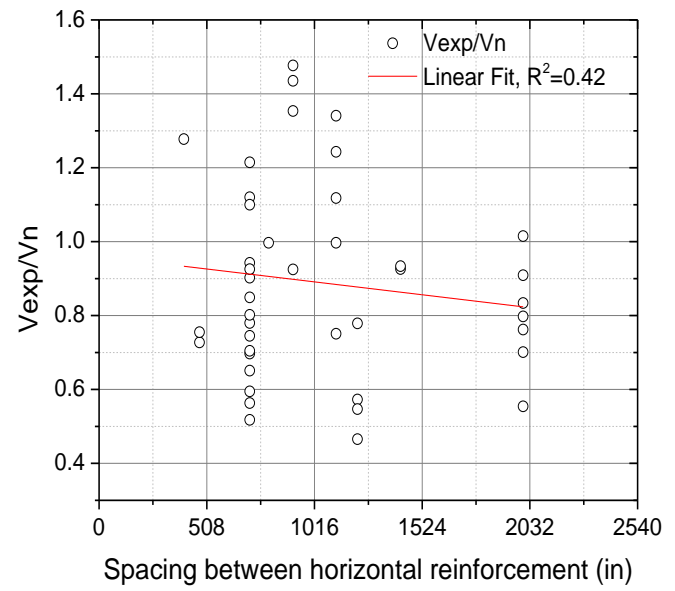

(d) Spacing of horizontal reinforcement

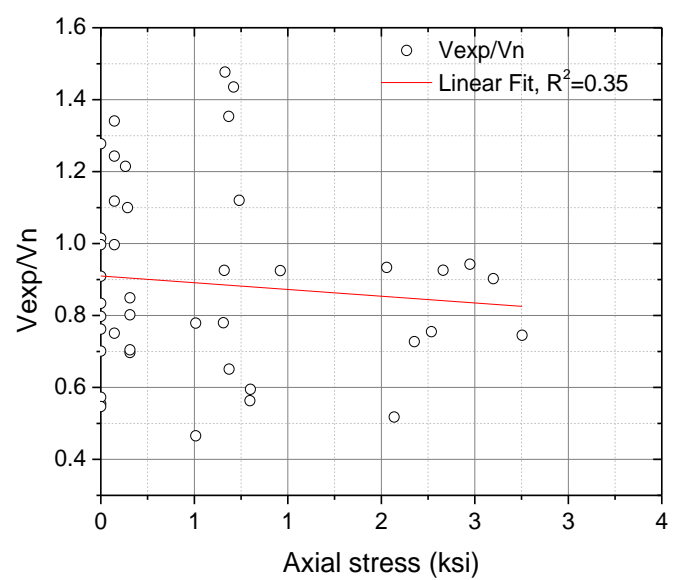

(c) Level of axial stress, $\sigma$
7

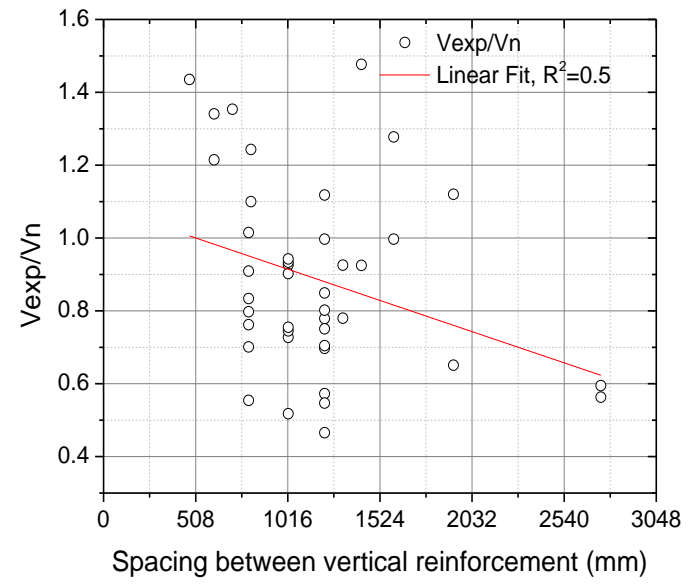

(e) Spacing of vertical reinforcement

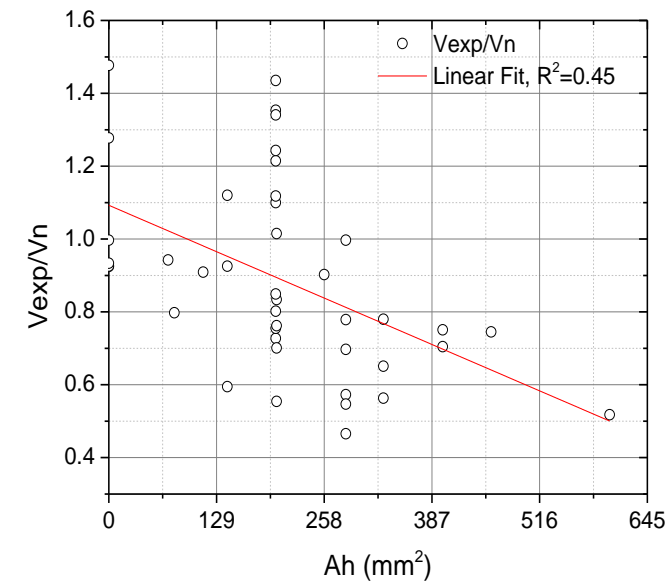

(f) Area of horizontal reinforcement

Fig. 9 Effect of different parameters on TMS (2016) expression accuracy 


\subsection{Masonry contribution}

As can be noted from Fig. 9, low aspect ratio of the wall and high $f_{m}^{\prime}$ value led to

3 lower ratios of experimental to predicted strengths using TMS (2016) expression. As the

4 aspect ratio decreases, the term $\left(4.0-1.75 \frac{M}{V L}\right)$ increases. Therefore, the masonry

5 contribution becomes higher and consequently, the shear expression becomes more

6 unconservative. This increase in masonry contribution can be also attributed to $f_{m}^{\prime}$, since

7 by increasing this parameter, the shear expression prediction becomes higher than values

8 predicted experimentally. Although, a new reduction factor has been introduced to

9 compensate the code over-prediction, these results are still in parallel with [16] findings

10 that were based on [11], showing that [11] expression is unconservative.

\subsection{Axial stress}

The level of axial stress (based on net area) has a little effect on the accuracy of the

14 TMS (2016) expression (Fig. 9c). It should be noted that the results were match with the 15 test results before applying the reduction factor in TMS (2016) expression. However, 16 applying the new reduction factor has a significant effect on overestimating the shear 17 strength. By considering the effect of axial stress [16] showed that the average of trend line 18 has about $20 \%$ difference with the experimental results in its maximum state.

\subsection{Shear reinforcement}

21

In accordance with Fig. 9d, spacing between bond beams has an insignificant effect

22 on the accuracy of TMS (2016) expression. However, as the amount of horizontal steel 23 increases the TMS (2016) expression becomes more unconservative. This is also in 
agreement with [31] findings on the effect of shear reinforcement. This issue was

2 addressed for the first time by [4]. They argued that the insignificant effect of the

3 horizontal shear reinforcement is due to the insufficient bar development length especially

4 at the lower and upper level of bond beams where diagonal shear cracks cross at the ends

5 of the reinforcement.

6

7

8 9 limiting the development length and possible contribution from horizontal reinforcement

Reduced contributions of horizontal shear reinforcement are a combination of the fact that shear cracks are localized near the wall edges at the top and bottom of walls, thus spanning the crack. In addition, historically it was not possible to test true full-scale masonry (e.g. $5 \mathrm{~m}$ floor heights, $6 \mathrm{~m}$ wall lengths) and as such the smaller 'piers' that could be accommodated in structures labs would unlikely have sufficient wall length to develop horizontal reinforcement spanning cracks even where the crack appears in the middle of the wall. Furthermore, since design standards rely on full yield strength of horizontal reinforcement as their basic assumption then shouldn't it be the onus of the designer of record to first theoretically determine necessary the development length of the horizontal reinforcement then the location of the principal shear crack and then what force could be carried by each reinforcing bar at each discrete crack location. This would be similar to how in-plane flexure is designed for, whereby not all vertical bars are necessarily yielding.

0
is also investigated and plotted in Fig. 9f. As previously described, TMS (2016) expression is developed for FG reinforced masonry. Therefore, this parameter is not included in the 
1 shear expression. From the results given in the plot, it can be observed that increasing the

2 vertical spacing between cells increases the over-prediction of the TMS (2016) expression.

3 TMS (2016) expression reasonably predicts the shear strength of PG walls with horizontal

4 and vertical grouted cells spaced up to $1.2 \mathrm{~m}$, becoming less accurate for greater values.

5 Hence, this research focuses on developing a shear expression for ordinary PG masonry

6 walls with grout spacing larger than $1.2 \mathrm{~m}$.

7

\section{5. Investigating the infilled-frame mechanism of PG walls}

Applying a diagonal load to an ungrouted masonry panel led to an abrupt tensile

10 failure initiated by a stepped crack at the block-mortar interfaces. In the grouted

11 specimens, however, the failure plane followed a straight line through a combination of

12 head joints and masonry units. This behavior was investigated experimentally by [34] and

13 numerically by [36 and 17] using ANSYS 5.3 [37] and Abaqus 6.10 [38] finite element

14 programs, respectively. Fig. 10 shows the test specimen and test setup representing the

15 standard diagonal tension test [39] in addition to the finite element model employed to

16 simulate the specimen. The minimum principle stresses of diagonal tension specimen are

17 plotted in Fig. 11. Plots show that as the diagonal load increases compression struts start to

18 form, reaching three struts before failure takes place (Fig. 11). These compression zones

19 are forming between the head joints. 

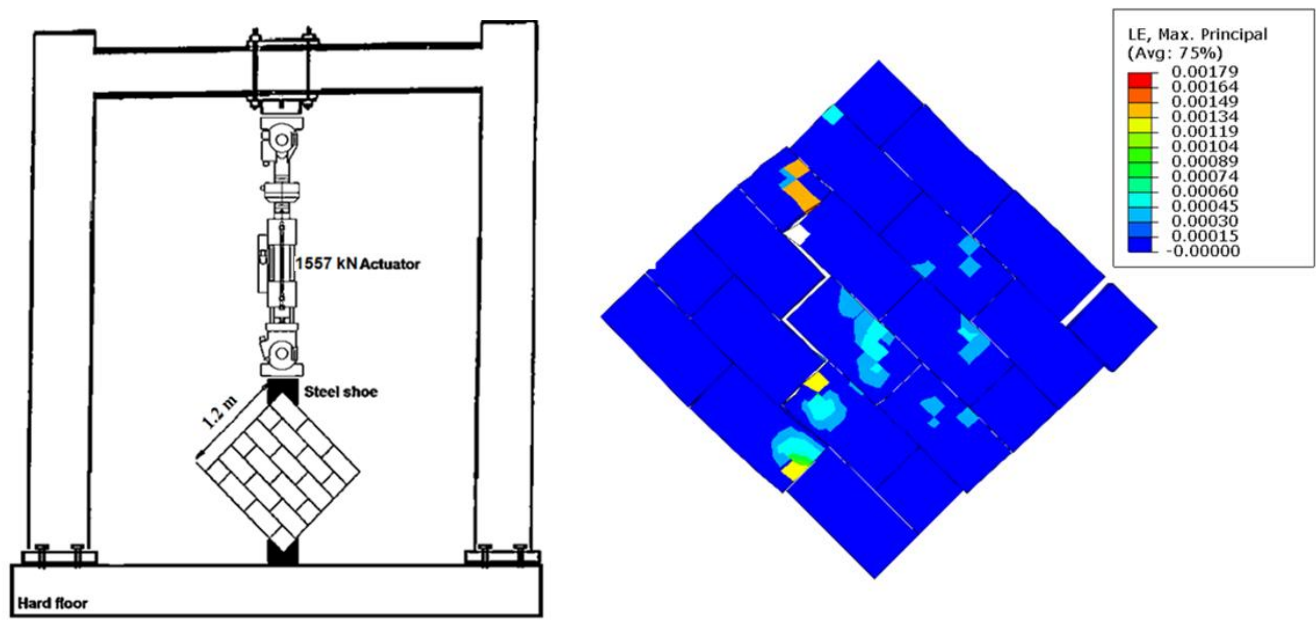

Fig. 10 Diagonal tension specimen [15]
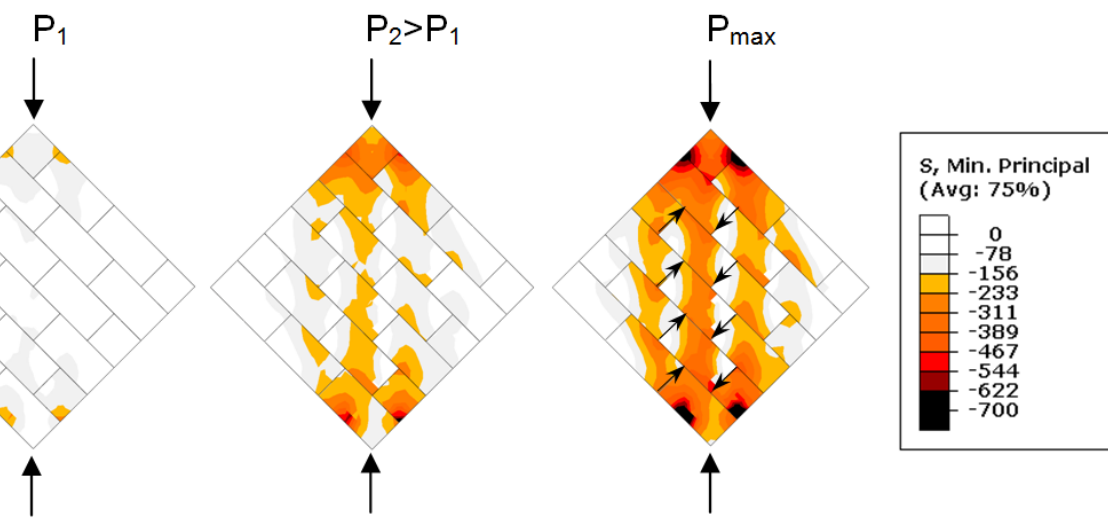

Fig. 11 Minimum principal stress contours obtained at different load stages using Abaqus

As opposed to the ungrouted masonry panel, when a diagonal crack initiates within an infilled-frame, it can still carry load due to the partial confinement that the frame offers to the infill panel. This partial confinement prevents sudden failure of the panel and provides more strength and deformation capacity to the masonry panel [40-42]. Separation between the frame and the infill panel reduces the contact length. However, even this confinement would be enough for new diagonal cracks to form within the panel until reaching its ultimate strength (Fig. 12a). [40] reported that the tensile stress is equal to zero at both ends of the tensile diagonal path of infilled-frames and reaches maximum at the middle of the diagonal. This scenario for compressive stress is reverse (Fig. 12b). 
relative stiffness. Results illustrated that the central strain of the infill is not sensitive to the contact length and frame stiffness. This mechanism is very similar to steel plate shear wall with infill and the same results were reported in [43 and 44]. However, as can be seen from Fig. 13, the corners strain is highly affected by contact size and frame stiffness.

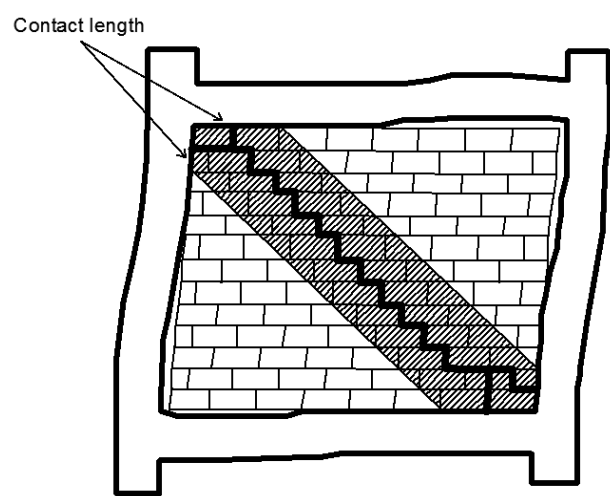

a) Forming strut

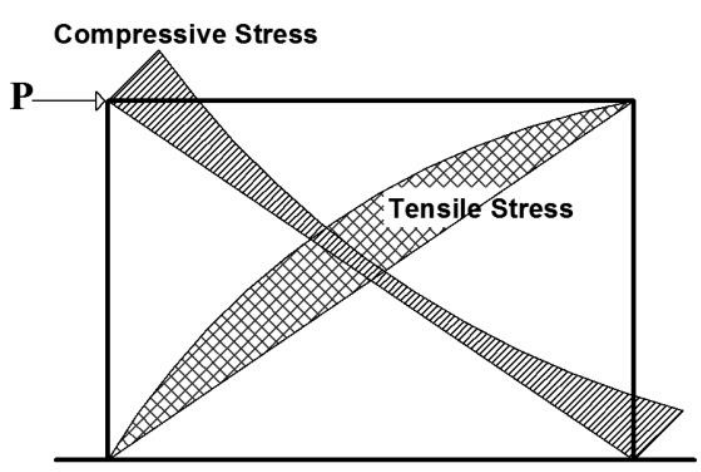

b) tensile and compressive stresses distribution on infilled-frame

Fig. 12 Strut mechanism and stress distribution of infilled-frame [39]

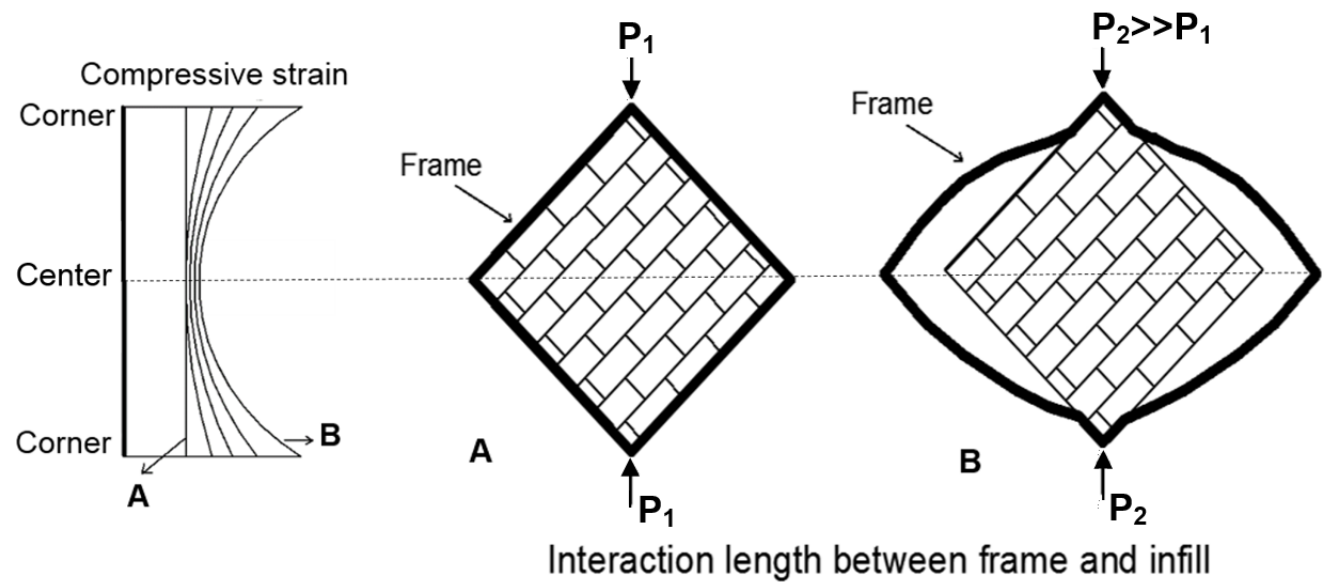

Fig. 13 Compressive strain distribution along compressive diagonal length for different 
Three types of crack can be recognized in infilled-frames: crack at the boundaries,

2 diagonal, and toe crushing cracks [40]. Discontinuities between the frame and the infill

3 during the pushover test which occurs close to the tensile zones are called boundary

4 cracks. These cracks form approximately at one tenth of wall strength [40] by referencing

5 the load displacement curve of an infill-frame. These cracks do not have any bearing on the

6 strength of frames and only reduce the initial stiffness of the frame. The force-displacement

7 relationship remains linear after the presence of boundary cracks. Nonlinear-plastic

8 behavior of the infilled-frame begins with forming diagonal cracks at the center of the infill.

9 These cracks initiate at the center of the infill diagonal due to the high tensile stress. Infill

10 cracks are divided into two categories, tensile and shear diagonal cracks. Finally by

11 increasing the load, infill will be crushed at the corners showing dramatically reduced

12 stiffness or forming plastic hinges in the frame. All these mechanisms were also observed

13 in PG walls [2, 15, 16 and 18]. Fig. 14 is depicting the crack propagation and different load-

14 displacement stages for an infilled-frame structure.

15

16

17

18
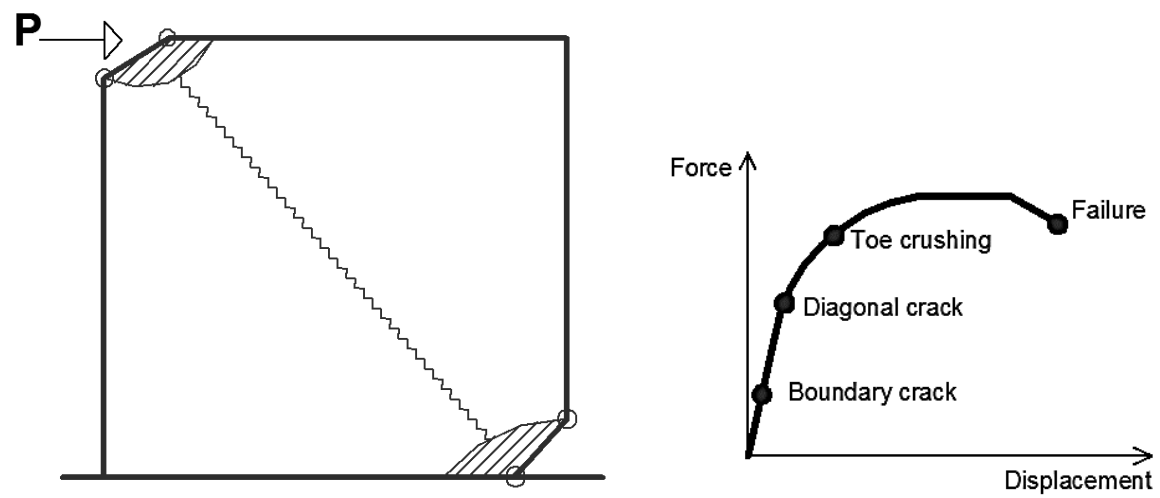

Fig. 14 Failure mechanism [40] 
PG masonry walls consist of hollow and grouted portions that include reinforcing bar. The behavior of vertical grouted cells and horizontal bond beams (grouted parts) are 3 similar to the reinforced concrete frame, differing in that RC frames have more

4 reinforcement in the concrete elements than grouted masonry elements. Although the 5 strength of reinforced cells of PG walls is not the same as common reinforced concrete 6 frame, the overall behavior of these two systems is alike. Although the behavior of grouted 7 parts of PG masonry and RC frame is similar, there is a distinct difference in the interaction 8 mechanism between a masonry frame and infill with that of infilled-frame. This 9 discrepancy is corresponded to the length of units exceeded from vertical grouted cells. 10 This can be noted from Fig. 15, a stepped-wise surface due to the unit interaction with the 11 infill instead of concrete frame straight plane. Therefore, the interaction mechanism of 12 infilled concrete masonry frame within the PG wall cannot be accurately described by [41] 13 model because of unit interlocking of the frame with the hollow infill. Since grouted frame 14 within the wall confines the hollow masonry infill, no separation can be observed between 15 the two elements. However, the infilled reinforced concrete frame behaves the same as 16 predicted by [41] model because of weak interaction between the RC frame and the 17 masonry infill due to the low cohesive bond and friction. 
1

2

3

4

5

6

7

8

9

10

11

12

13

14

15

16

17

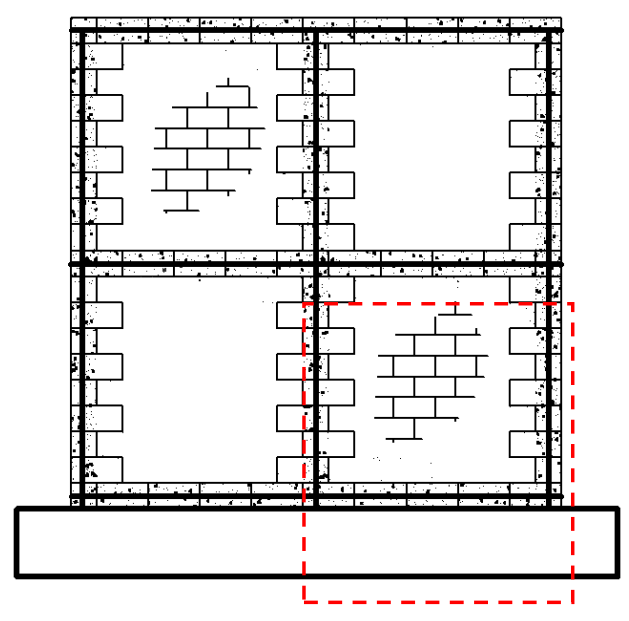

a) Grouted concrete masonry
frame as a part of the wall

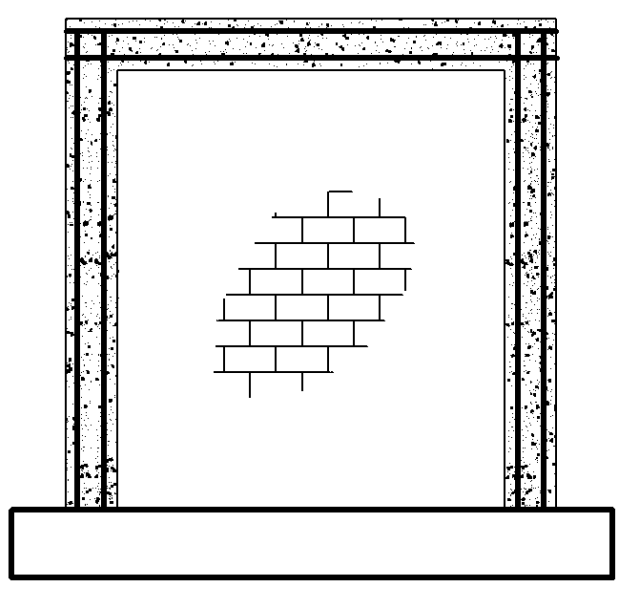

b) Reinforced concrete frame

Fig. 15 Interaction of infill with frame

To investigate the infilled-frame mechanism in PG walls, a simplified micro model of PG walls was tested experimentally by [17 and 18] and built in Abaqus. A simplified 3D micro model was employed to build the model by considering the units, the grout and their interfaces. Masonry units and grout are modeled as solid blocks and solid concrete, respectively. In order for simplicity, only the thickness of units' face-shells was considered when modeling the hollow units in the panels. Details of the model are presented in Table 4 and Fig. 16. Additionally, mortar joints and blocks are combined into a homogeneous unit material using Abaqus concrete damage plasticity (CDP) model. Interface elements were also employed to model the discontinuity between the hollow units using cohesive surfacebased behavior. This model was verified by the experimental results of grout, unit, mortar and hollow and grouted masonry assemblages [17]. It is worth mentioning that the model was able to successfully capture the stress and strain curve, crack pattern and strain 
1 distribution of hollow and grouted assemblages. As a result, the same model was employed

2 in the current study for modeling the wall specimens.

3

4

5

6

7

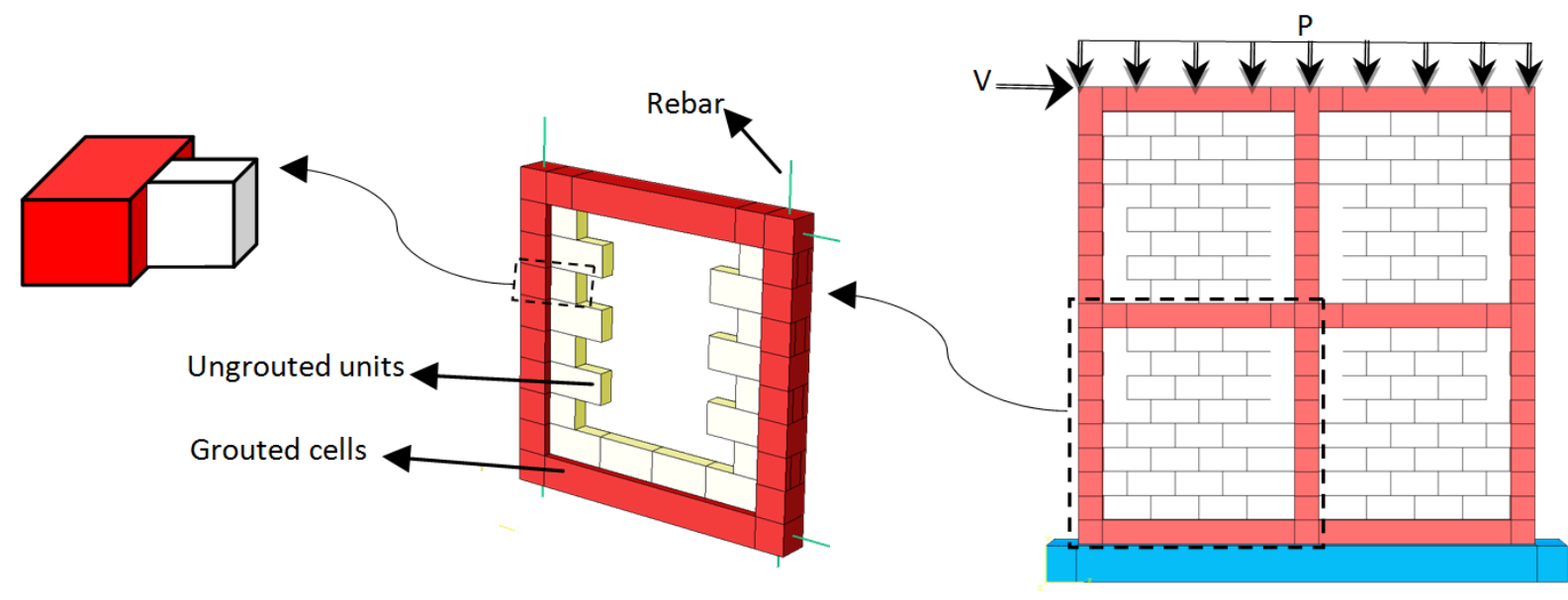

Fig. 16 Model detail

Table 4 Parameter of the model

\begin{tabular}{|c|c|c|c|c|c|c|c|}
\hline \multicolumn{4}{|c|}{ Hollow } & \multicolumn{4}{|c|}{ Grouted } \\
\hline $\begin{array}{c}\mathbf{E} \\
\mathbf{G P a}\end{array}$ & $\begin{array}{c}\text { Dilation } \\
\text { Angle } \\
\Psi\end{array}$ & $\mathbf{f b}_{0} / \mathbf{f c}_{0}$ & $\begin{array}{l}\text { Viscosity } \\
\text { Parameter }\end{array}$ & $\begin{array}{c}\mathbf{E} \\
\mathbf{G P a}\end{array}$ & $\begin{array}{c}\text { Dilation } \\
\text { Angle } \\
\Psi\end{array}$ & $\mathbf{f b}_{0} / \mathbf{f c}_{0}$ & $\begin{array}{l}\text { Viscosity } \\
\text { Parameter }\end{array}$ \\
\hline 26.2 & 32 & 1.16 & 0.001 & 33.7 & 34 & 1.16 & 0.001 \\
\hline \multicolumn{2}{|c|}{ Compressive Behavior } & \multicolumn{2}{|c|}{ Tensile Behavior } & \multicolumn{2}{|c|}{ Compressive Behavior } & \multicolumn{2}{|c|}{ Tensile Behavior } \\
\hline $\begin{array}{c}\text { Yield Stress } \\
\mathrm{MPa}\end{array}$ & $\begin{array}{c}\text { Inelastic } \\
\text { Strain }\end{array}$ & $\begin{array}{c}\text { Yield Stress } \\
\mathrm{MPa}\end{array}$ & $\begin{array}{l}\text { Cracking } \\
\text { Strain }\end{array}$ & $\begin{array}{c}\text { Yield Stress } \\
\mathrm{MPa}\end{array}$ & $\begin{array}{c}\text { Inelastic } \\
\text { Strain }\end{array}$ & $\begin{array}{c}\text { Yield Stress } \\
\mathrm{MPa}\end{array}$ & $\begin{array}{c}\text { Cracking } \\
\text { Strain }\end{array}$ \\
\hline 13.8 & 0 & 0.64 & 0 & 17.4 & 0 & 1.5 & 0 \\
\hline 17.2 & 0.00012 & 0.62 & 0.00006 & 20.7 & 0.0003 & 1.15 & 0.00029 \\
\hline 17.9 & 0.00032 & 0.34 & 0.00028 & 21.6 & 0.0005 & 0.83 & 0.00044 \\
\hline 13.8 & 0.00057 & 0.21 & 0.00045 & 20.9 & 0.0010 & 0.3 & 0.00092 \\
\hline 7.6 & 0.00131 & 0.12 & 0.00079 & 19.6 & 0.0015 & 0.1 & 0.00300 \\
\hline 4.4 & 0.00191 & 0.05 & 0.00139 & 15.1 & 0.0029 & 0.06 & 0.00450 \\
\hline 2.2 & 0.00245 & 0.03 & 0.00299 & 10.3 & 0.0045 & 0.05 & 0.00530 \\
\hline 1.0 & 0.00295 & 0.02 & 0.00349 & 2.0 & 0.0099 & - & - \\
\hline
\end{tabular}

8

9

Fig. 17 shows a comparison between the experimental and numerical results

10 regarding crack pattern and load displacement relationship for the singly grouted wall

11 specimen (please refer to [18] for more details). Before forming cracks at the edges of the 
1 wall, stepped-wise cracks initialized at the center of the hollow panels due to the shear

2 action. The size of the cracks at the middle of the hollow panels increased as the lateral

3 imposed displacement increased. Higher tensile stress concentration with increased load

4 caused these cracks to widen diagonally to ultimate failure of the infill masonry. With

5 increasing the lateral load cracks developed at the edges of the hollow panel, close to the

6 intersection between the middle bond beam and the vertical grouted cells. Finally, these

7 cracks propagated in the grouted cells because of weak connection (using a single bar in

8 the wall) between the lower bond beam and the vertical grouted cells. As a result, no

9 coupling took place and a large portion of the load was transmitted directly through the

10 frame to the wall toes causing toe crushing.

11

The same mechanism was observed in the numerical model. The minimum principal stress of the wall at different stages of the test is plotted in Fig. 17. As shown in Fig. 17i, wall behaves elastically up to point $d$ and reaches to the maximum load at point $f$, test was stopped by criterion that the degradation of load fell below $80 \%$ of the maximum load (point g). It can be seen that in the elastic zone both the frame and the infill contributed in load carrying by showing stress distribution at the edges of the frame and forming uniform struts in the infill (Figs. 17a to $17 \mathrm{~d}$ show how compression struts are forming). At the maximum load, five struts in each panel and the frame were carrying the load, as shown in Fig. 17f. Additionally, plastic hinges began to form in the frame. At the failure point, the number of struts become less by forming diagonal cracks in the panels and these strut mechanisms cannot transfer the load anymore. 
a)

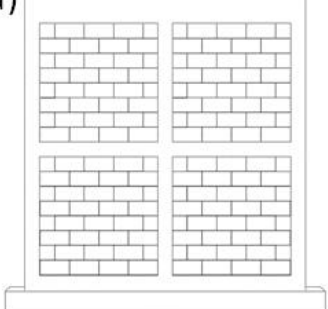

b)

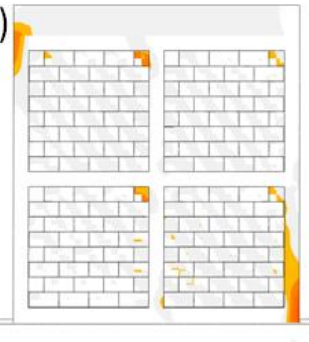

e)

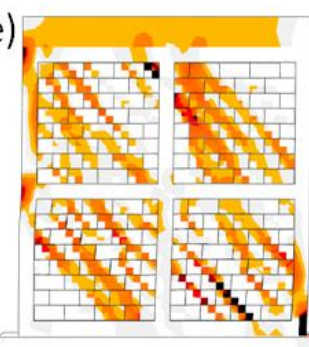

f) c)
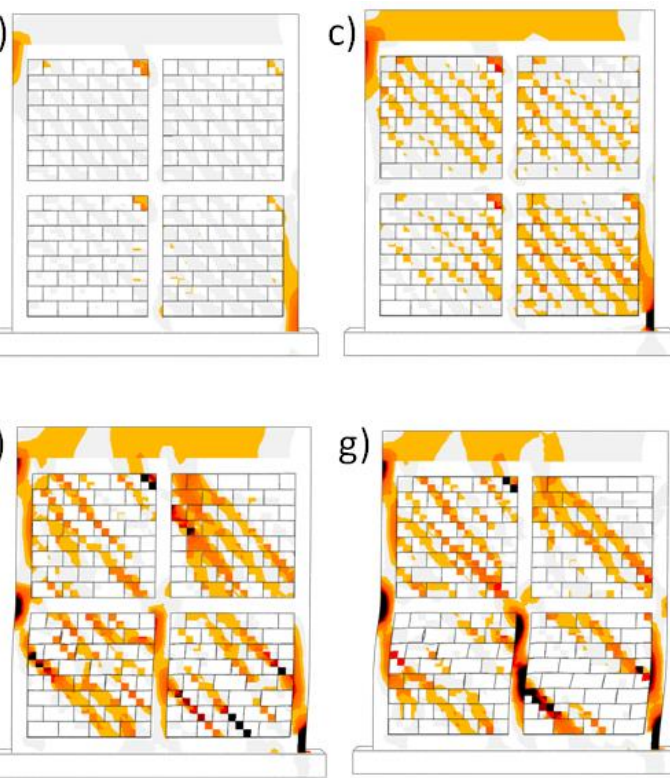

g)

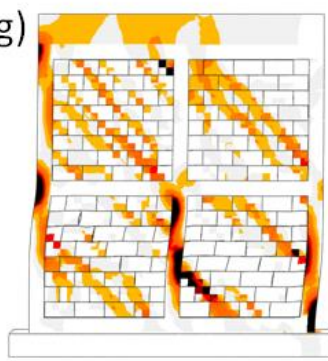

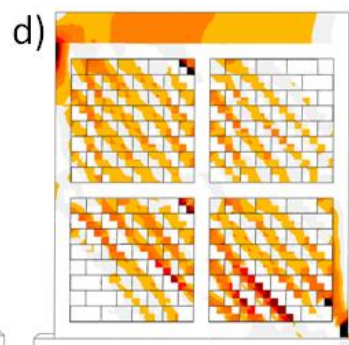

h)

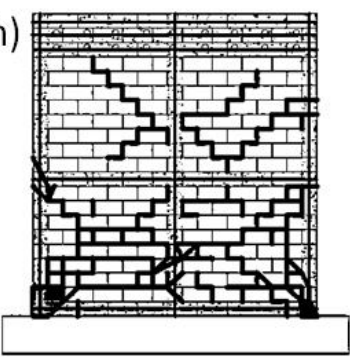

S, Min. Principal (Avg: 75\%)

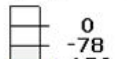

年- $\begin{array}{r}-78 \\ -156\end{array}$

-33

311

-389
--467
-544

$-544$

a-g) Minimum principal stress at different stages of applying load, h) Experimental final crack pattern

Fig. 17 Numerical and experimental results for singly grouted wall

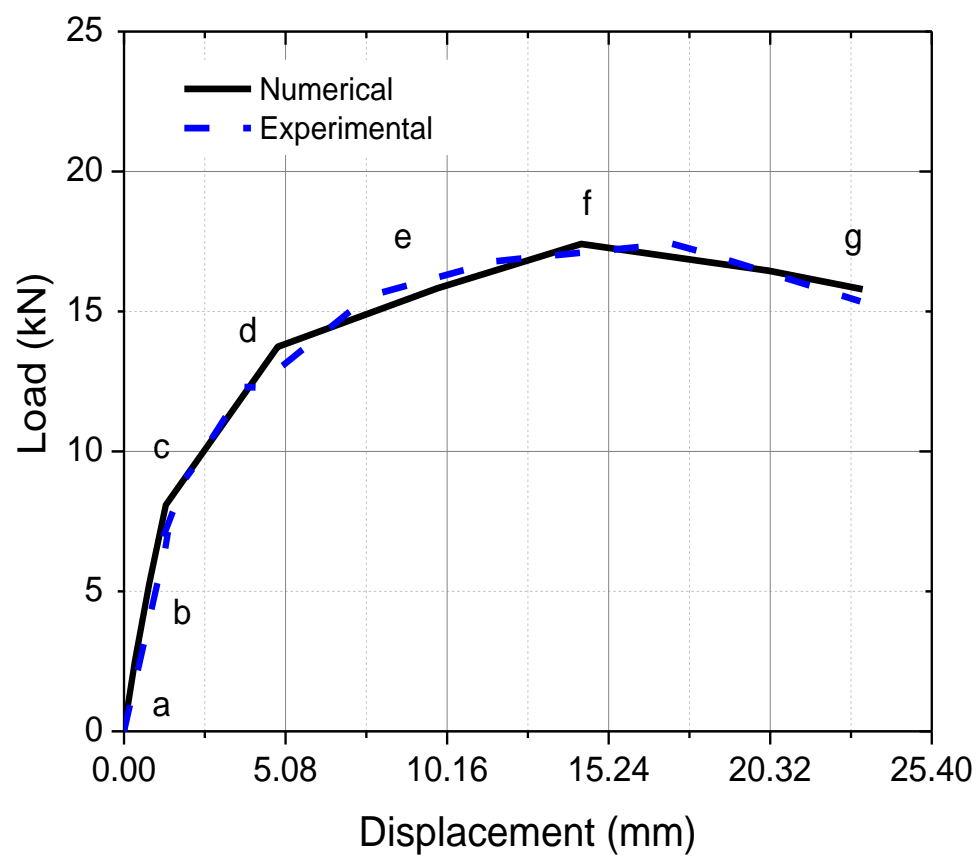

7

i) Experimental and numerical load-displacement curves

Fig. 17 Numerical and experimental results for singly grouted wall (contd.) 

remaining. At this load level, the frame assumes the role of vanished struts, and as can be

3 seen in Fig. 17g, numbers of plastic hinges form in the frame due to the high load present.

4 Although, the top part of the wall can still carry additional load, the wall fails due to the

5 failure at the bottom of the wall which is attributed to both panel and frame. The numerical results are generally in good agreement with the test results at different stages. Not only

7 are the final results of the test predicted, but the model is able to show the mechanism of stress pattern in the wall. It can be concluded that mechanical properties of the PG wall can

9 be simulated using infilled-frame concept. However, these struts are formed based on the number of restrained half units in the grouted cells, see Fig. 18.

Fig. 18 shows the number of struts schematically that are attributed to the wall 13 load-carrying mechanism at peak load (Fig. 17f). The width of all struts are the same and 14 can be approximately equal to: $w=\frac{L_{u}}{2} \sin \theta$, where $l_{u}$ is the length of the unit, as shown in $15 \quad$ Fig. 18.

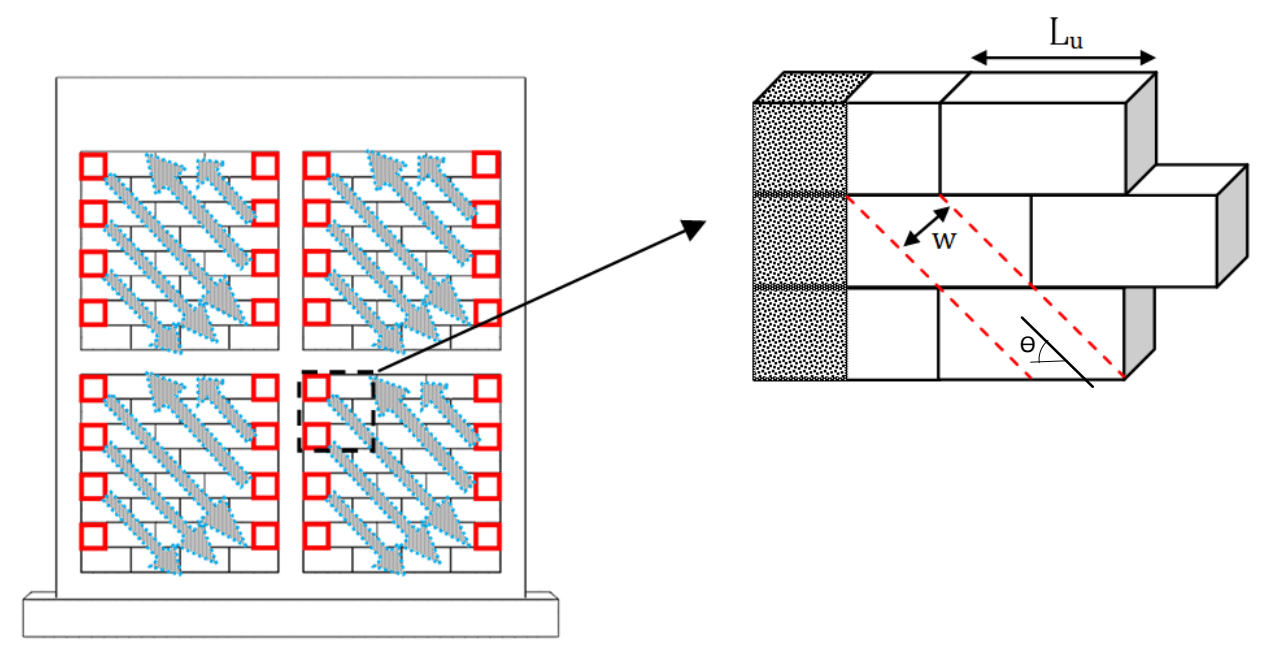

Fig. 18 Strut configuration 


\section{6. Proposed shear strength expression}

shear strengths. Therefore, the below expression is proposed for calculating the shear

4 strength of PG wall based on the infilled-frame theory.

$5 \quad V_{n}=V_{\text {infill }}+V_{\text {frame }}$

$6 \quad$ where, $V_{\text {infill }}=V_{\text {masonry }}+V_{\text {load }}$

7

8

6

\subsection{Infill contribution}

As per Fig. 19, this idealization is simple and intuitive to use in conventional computer codes for analysis of frames. Since the masonry infill is idealized as an equivalent strut, the forces in the frame elements bounding the infill must be slightly adjusted. To design the infill, the force in the equivalent diagonal strut should be calculated followed by comparing it with the strength of the infill.

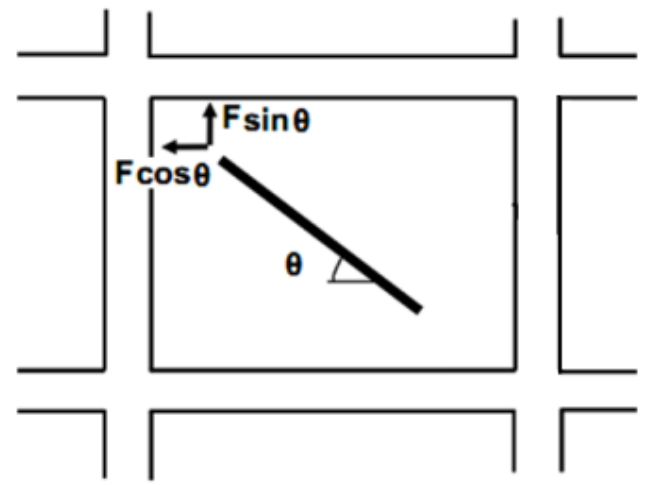

Fig. 19 Idealization of equivalent strut

As discussed earlier, three struts are formed while the wall reaches at its peak. These struts as presented in the numerical modeling are formed based on the compression stress flow in the infills. Compression struts in the wall are idealized with three uniform 
1 struts as depicted in Fig. 17b. The middle strut is the only one which reaches its ultimate

2 strength and as seen in Fig. 17g, this strut disappears after the peak stage. Since the other

3 struts are functional even after the peak, instead of considering three struts, one equivalent

4 strut has been assigned to each panel, shown in Fig. 20c, for the analytical purpose and

5 simplification of the shear expression. The horizontal components of these struts would be

6 equal to the shear strength of each panel.

7

8

9

10

11

12

13

14

15

16

17

18

19

20

21

22

23

24

25

26

27

28

29

30

31

32

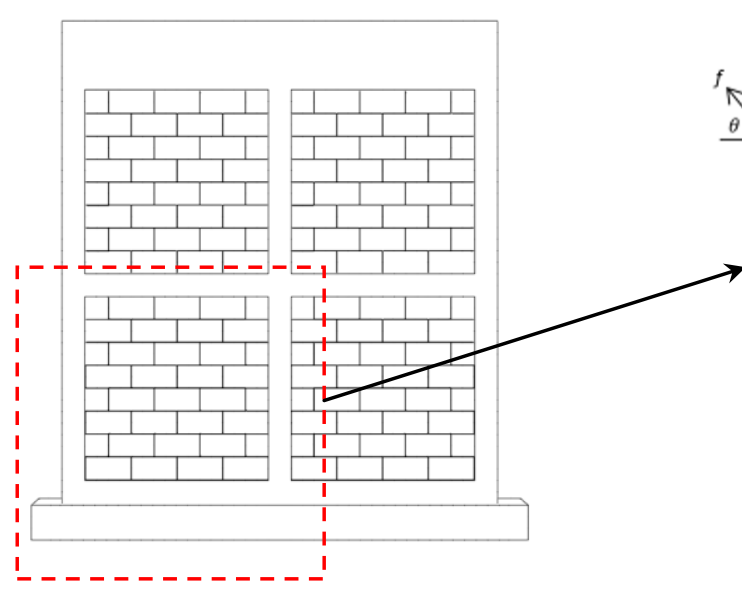

(a) PG wall

(b) Three struts model

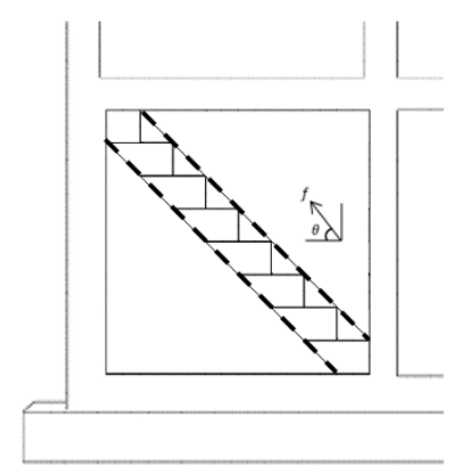

(c) Equivalent strut

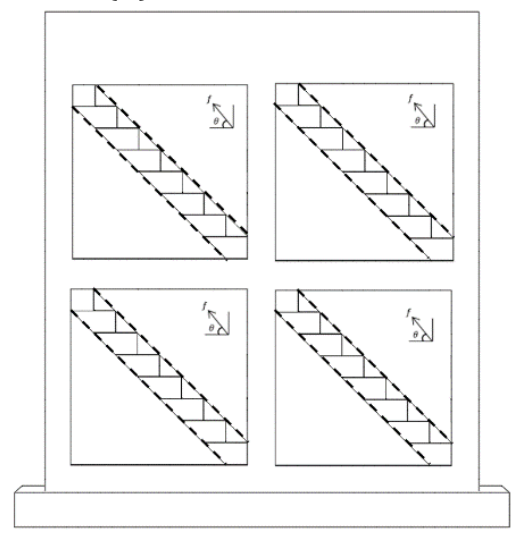

(d) Equivalent PG wall

Fig. 20 Idealization of equivalent strut

36

37

Infills have been shown by experiment to have three possible failure modes: local 
1 the infilled bay, and a shearing failure of the infill along a bed joint. Since the effect of

2 confinement was considered in forming different struts, even after they cracked, the shear

3 failure strength of diagonal tension specimens is considered here as the ultimate strength

4 of struts (Eqs. 13 and 14). Shear cracks in masonry without shear reinforcement cannot be

5 tolerated, propagating into compression faces and reducing effective compression areas

6 which are meant to resist shear. Therefore, the nominal shear stress at which diagonal

7 tension cracks form and propagate can be written as $V_{c}=2 A \sqrt{f_{c}^{\prime}}[45]$.

$8 \quad \tau_{D T}=2 \sqrt{f_{m}^{\prime}}$

$9 f=2 A_{\text {strut }} \sqrt{f_{m}^{\prime}}$

10 where, $A_{\text {strut }}$ is $w t_{\text {eff }}$. Where, teff is the effective wall thickness, for example in a

11 fully grouted wall this is equal to the total width of unit, however in the hollow masonry it

12 would be equal to thickness of faceshells. Therefore, the horizontal component of shear

13 strength in each panel can be calculated as below:

$14 V_{\text {masonry }}=2 w t_{\text {eff }} \sqrt{f_{m}^{\prime}} \cos \theta$

After crack initiation the panel can still carry load due to friction. The Coulomb's law

16 expression for shear strength due to friction has been implemented here, however, the

17 cohesive term will be ignored due to the presence of diagonal crack in the panel. Therefore,

18 the extra shear strength due to the presence of axial load can be written as;

$19 \quad V_{\text {load }}=\mu P_{\text {infill }}$

20 where, $P_{\text {infill }}$ is defined based on the relative stiffness between frame grouted cells 21 and infilled components and the vertical component of equivalent struts (Eq. 15). This is 
1 associated to the ratio of panel area to that of grouted cells. It should be noted that only half

2 of each grouted cell located in the center is involved for a single panel.

$3 \quad P_{\text {infill }}=\frac{P * A_{\text {infill }}}{(n-1)\left[A_{\text {infill }}+1.5 A_{\text {vertical grouted cell } s}\right]}+\frac{w t_{e f f} \sqrt{f_{m}^{\prime}} \sin \theta}{(n-1)}$

4

$5 \quad A_{\text {vertical grouted cells }}=A_{\text {grouted cells }}+A_{s}\left(\frac{E_{\text {steel }}}{E_{\text {grout }}}-1\right)$

Finally, the shear strength of each panel is driven by summation of $V_{\text {masonry }}$ and

$7 \quad V_{\text {load }}$ as following;

$8 \quad V_{\text {infill }}=2 w t_{\text {eff }} \sqrt{f_{m}^{\prime}} \cos \theta+\mu P_{\text {infill }}$

\subsection{Frame contribution}

No base moments are considered for the frame due to the use of the single bar in the

12 grouted cells as a common detail configuration of PG walls. The shear strength that frame

13 can obtain is considered only based on the plastic hinges forming in the vertical grouted

14 cells. There are two scenarios concerning to infilled-frame strength; weak frame-stiff infill

15 and strong frame-weak infill. Weak frame-stiff infill mechanism due to the small amount of

16 reinforcement in grouted cells and bond beams was observed in the numerical and

17 experimental study as discussed earlier (Fig. 21 indicates the number and location of these

18 mechanisms). The shear resistance of the frame in each panel, can be expressed as

19 following expression by taking moment about point $A$ in the column segment $A B$ :

$20 \quad V_{\text {panel }}=\frac{4 M_{p}}{h}$

So the total shear strength of the frame would be; 
$1 \quad V_{\text {frame }}=\frac{4(n-1) M_{p}}{h}$
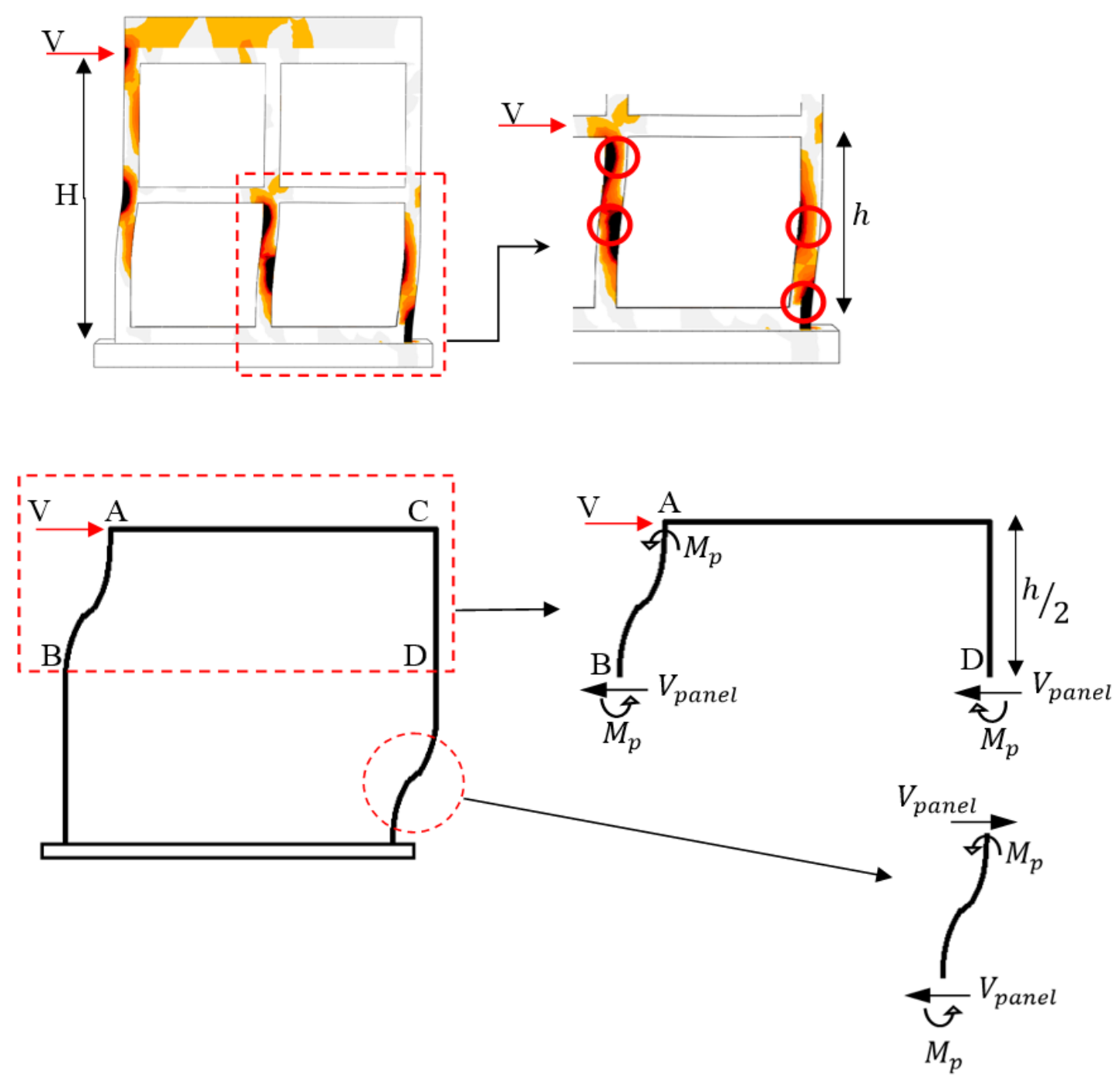

Fig. 21 Failure mode shapes, location of plastic hinges and force diagram for the frame

4

where, $h$ is the space between the first two horizontal bond beams at the bottom of

6 walls as shown in Fig. 22 and also $n(\geq 2)$ is the number of vertical grouted cells (piers) and

7 will be discussed in the next part for generalizing the expression for different PG masonry configurations. 


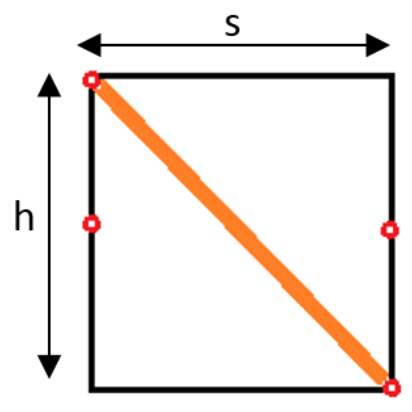

$\mathrm{n}=\mathbf{2}$

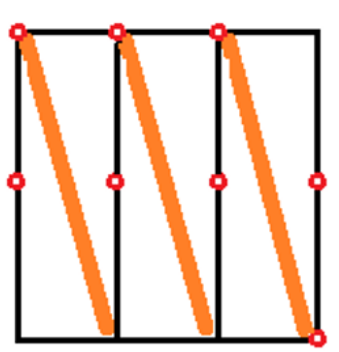

$\mathrm{n}=4$

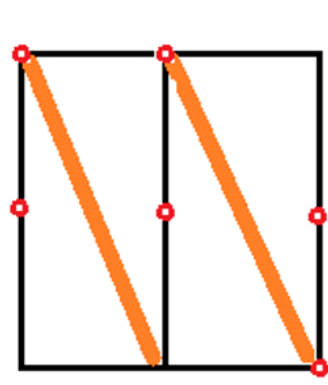

$n=3$

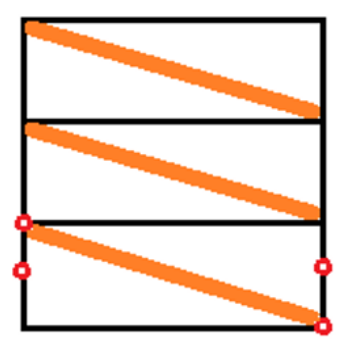

$\mathrm{n}=\mathbf{2}$

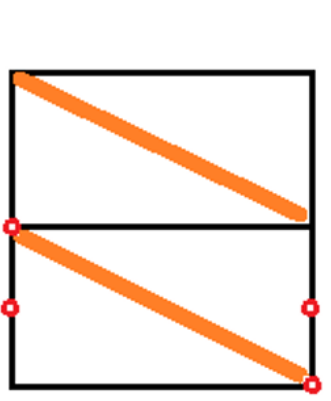

$n=2$

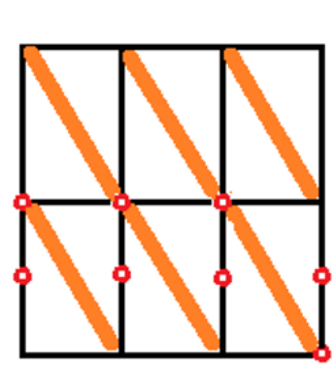

$\mathrm{n}=4$

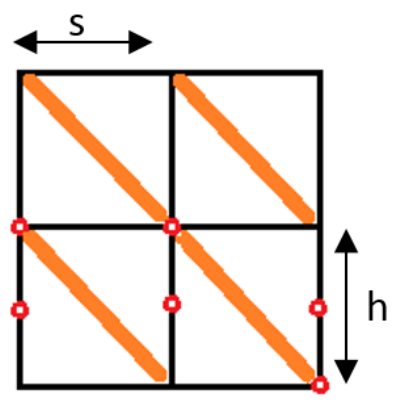

$n=3$

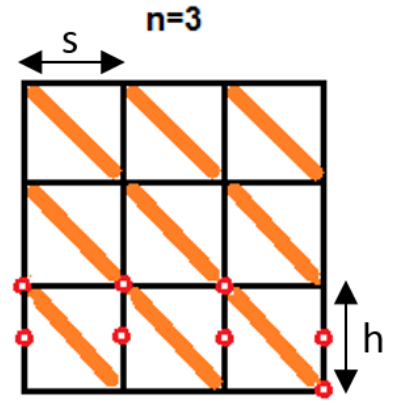

$n=4$
$6 n=\frac{L}{s}+1$

where, $L$ is the wall length and $s$ is grout spacing. Therefore, the general shear

$V_{n}=(n-1)\left[w t_{\text {eff }} \sqrt{f_{m}^{\prime}} \cos \theta+\mu P_{\text {infill }}+\frac{4 M_{p}}{h}\right]$

It is to be noted that the proposed expression is best applicable to walls with

12 vertical and horizontal grout spacing more than $1.2 \mathrm{~m}$. While walls with grout spacing less

13 than $1.2 \mathrm{~m}$ acting more like a monolithic wall, TMS (2016) expression is good enough to be 14 used. 


\section{Parametric study and model verification}

The model was used to predict the shear strength of three walls that were tested. Data needed for calculating the shear strength of these walls are presented in Table 5. The shear strength of walls is calculated based on the Eq. 21. $P_{\text {infill }}$ is calculated followed by procedure in Eqs. 15 and 16, it can be seen that wall DR infill carries 17\% load less than wall SR. In another word, frame taking more axial load by grouting the double cells instead of one. Model predicted the shear strength of SR, DR and SRO walls of $160 \mathrm{kN}, 207 \mathrm{kN}$ and $232 \mathrm{kN}$, respectively. The model showed 5\%, 6\% and 15\% errors in predicting the shear strength of these walls compared to the experimental values. This excellent agreement clearly demonstrates adequacy and efficiency of the analytical model used in this study.

In order to investigate the effect of different parameters presented in the Eq. 22 on the shear strength formula, a simple parametric study is reported here. To do so, the effects of parameters; $n, f_{m}^{\prime}, P$ and $M_{p}$ are studied. In each try, all other numbers were considered constant using $194 \mathrm{~mm}, 65 \mathrm{~mm}, 0.7,0.25$ and $3.0 \mathrm{~m}$ values for $w, t_{\text {eff }}, \cos \theta, \mu$ and $H$, respectively and results are plotted in Fig. 23. It is notable that $n$ and $\mu$ as expected, have a considerable effect on the shear strength formula and doubling the number of vertical grouted cells almost doubled the shear strength of the wall. Frame (reinforced grouted vertical cells) plastic moment, having a direct effect on the shear strength is the next important parameter. Results showed that increasing the size or number of vertical grouted cells increases the shear strength that frame can carry. Consequently, the shear strength of the wall increases. However, masonry compressive strength and axial load parameters show insignificant effects. 
Table 5 Summary of data used in the proposed model for SR and DR walls

\begin{tabular}{|c|c|c|c|c|c|c|c|c|c|c|c|c|c|c|c|}
\hline \multirow[t]{2}{*}{ ID } & $P$ & $\begin{array}{l}\text { Grouted } \\
\text { cells }\end{array}$ & $\begin{array}{l}\text { Area vertical } \\
\text { Grouted cells }\end{array}$ & infill & \multirow{2}{*}{$\begin{array}{l}\mu \\
-\end{array}$} & \multirow{2}{*}{$\begin{array}{l}\mathrm{n} \\
-\end{array}$} & \multirow{2}{*}{$\begin{array}{c}\mathrm{f}_{\mathrm{m}} \\
\mathrm{MPa}\end{array}$} & \multirow{2}{*}{$\begin{array}{c}\mathrm{h} \\
\mathrm{mm}\end{array}$} & \multirow{2}{*}{$\begin{array}{c}\mathrm{t}_{\mathrm{eff}} \\
\mathrm{mm}\end{array}$} & \multirow[t]{2}{*}{$\alpha$} & \multirow{2}{*}{$\begin{array}{c}\text { As } \\
\mathrm{mm}^{2}\end{array}$} & \multirow{2}{*}{$\begin{array}{c}\mathrm{f}_{\mathrm{y}} \\
\mathrm{MPa}\end{array}$} & \multirow{2}{*}{$\begin{array}{c}\mathrm{w} \\
\mathrm{mm}\end{array}$} & \multirow{2}{*}{$\begin{array}{c}\mathrm{M}_{\mathrm{pc}} \\
\text { MN.mm }\end{array}$} & \multirow{2}{*}{$\begin{array}{c}\mathrm{P}_{\text {infill }} \\
\mathrm{kN}\end{array}$} \\
\hline & $\mathrm{kN}$ & & $\mathrm{mm}^{2}$ & & & & & & & & & & & & \\
\hline$\overline{S R}$ & 58 & 37,636 & 113,000 & 35,436 & \multirow{3}{*}{0.25} & 2 & \multirow{3}{*}{15.3} & 1,627 & \multirow{3}{*}{66} & 15 & 258 & \multirow{3}{*}{414} & \multirow{3}{*}{194} & 8.1 & 28.1 \\
\hline DR & 50 & 75,272 & 226,000 & 31,015 & & 3 & & 1,424 & & 45 & 284 & & & 8.7 & 23.2 \\
\hline SRO & 213 & 37,636 & 113,000 & 35,436 & & 4 & & 813 & & 27 & 258 & & & 8.1 & 52.1 \\
\hline
\end{tabular}

3

8

9

10

11

12

13

14 


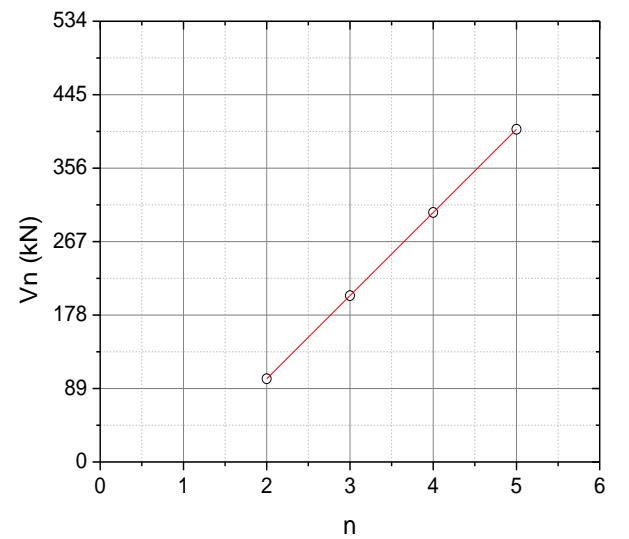

(a) Number of vertical grouted cells

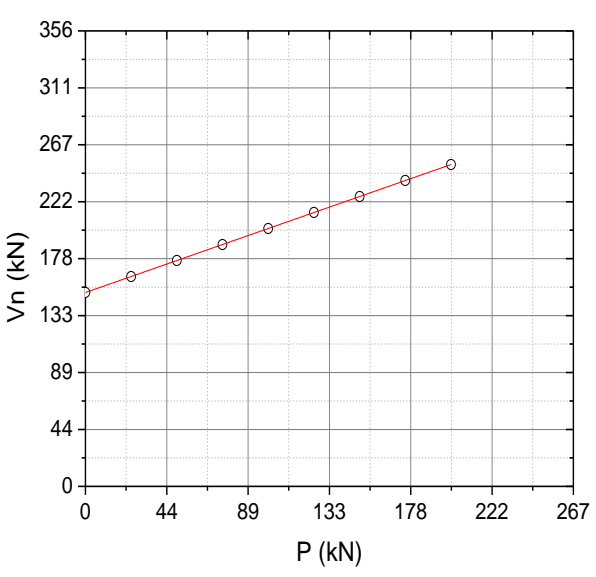

(c) Axial load

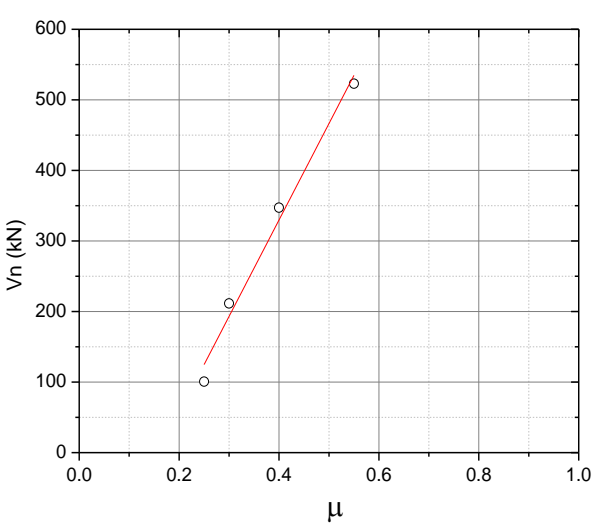

(e) Coefficient of friction

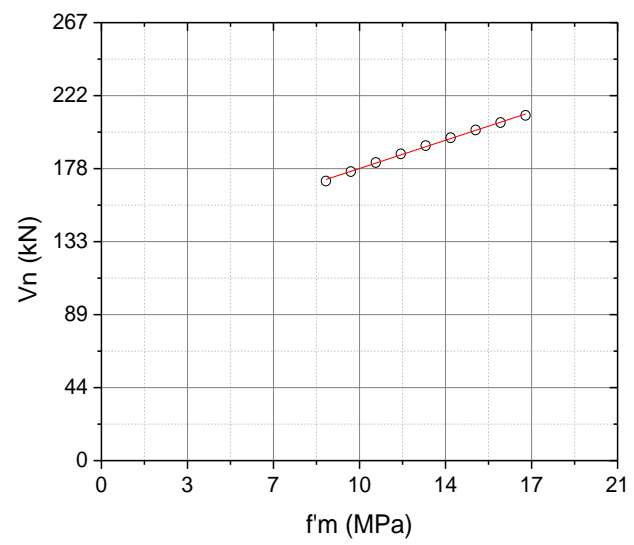

(b) Masonry compressive strength

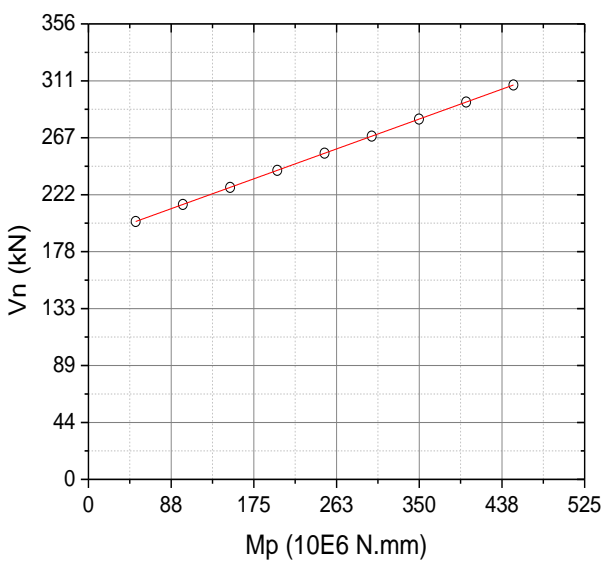

(d) Plastic moment

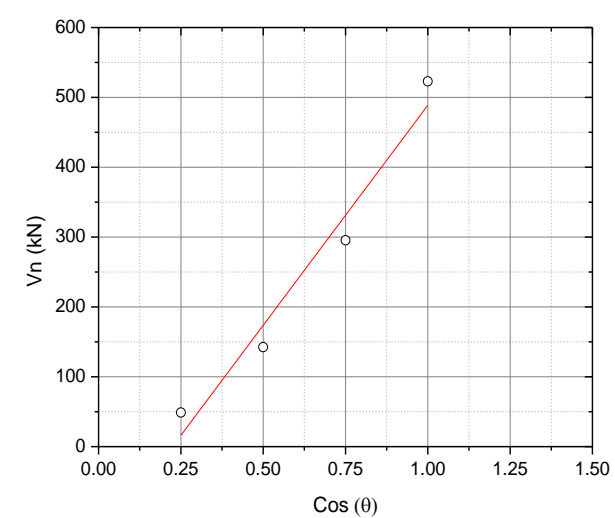

(e) Effect of $\theta$

Fig. 23 Parametric study 

in Fig. 24, in addition to shear strength predicted by TMS (2016) expression. In the most

3 cases, the model predicts the exact value of wall shear strength while in other cases model 4 tend to be more conservative.

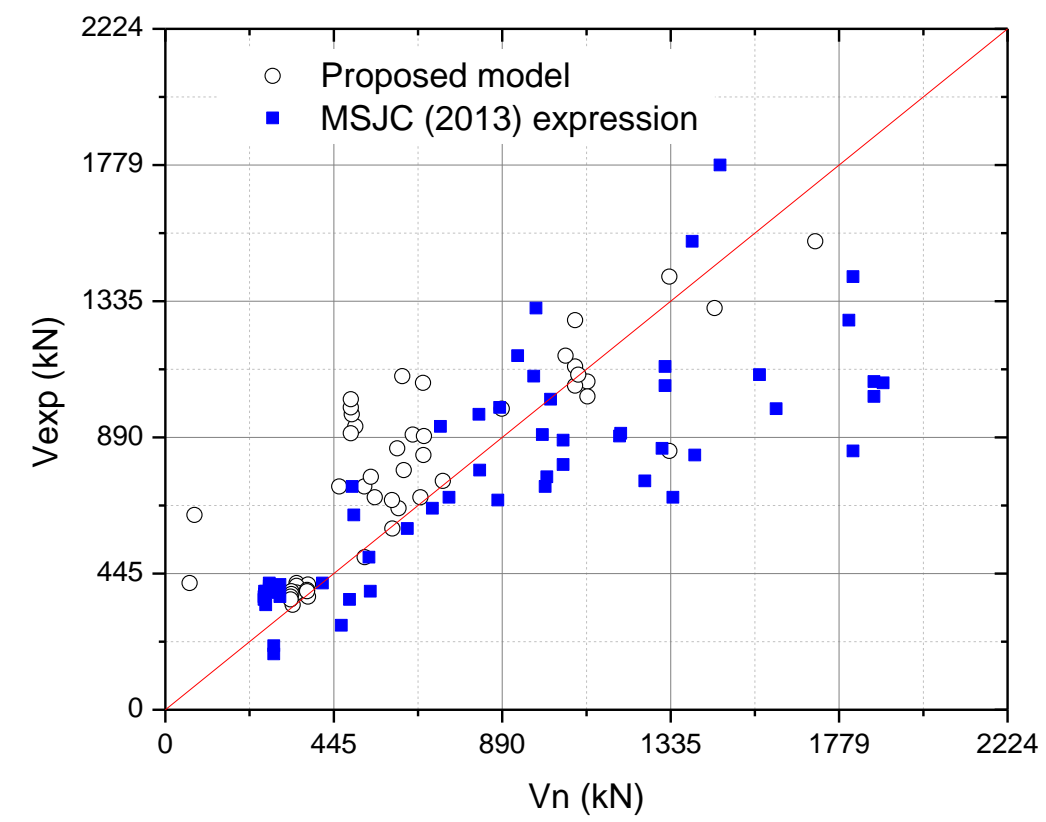

5

8
Fig. 24 Measured vs. nominal shear strength of database, TMS (2016) expression and proposed model

To see the different predicted shear strength given by the different equations, results of some of these equations are presented in Fig. 25. All equations have been applied on the data base presented in this study. Results showed that the proposed equation can accurately predict the shear strength of walls. However, the rest of the equations are unconservative. Results presented here are also in agreement with results reported in [16] that performed a similar analysis. 


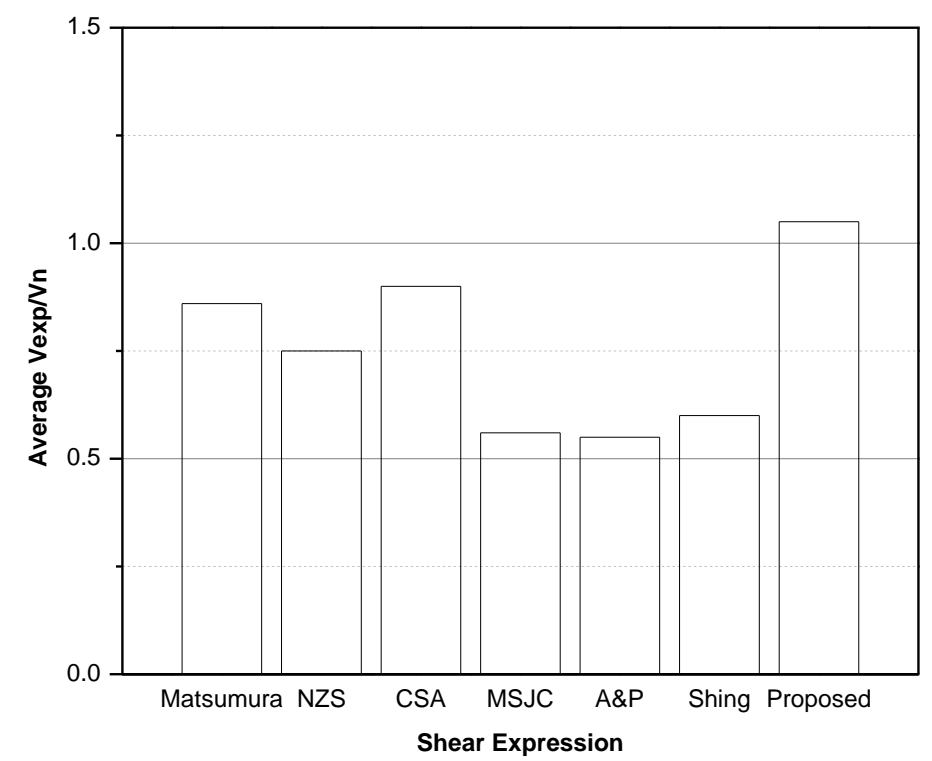

1

4 c. 25 Measured vs. nominal shear strength of database, TMS (2016) expression and proposed model

\section{Conclusions}

Results of this research revealed that even implementing $\gamma$ factor in the TMS (2016) expression has failed to solve the fundamental problem of the code shear expression. The current study introduced a new and more realistic approach to the shear strength mechanism of PG walls through adopting an infilled wall model as opposed to the monolithic wall model that already underpins the problem with the TMS (2016) expression. A new expression, therefore, was developed for PG walls based on infilledframe mechanism. It was concluded that shear mechanism of PG wall can be simulated using the infilled-frame concepts. This implies that the shear strength of PG walls is equal to the summation of the masonry infill and the frame shear strength. The infill masonry can be modeled by an equivalent strut in the wall. The shear strength the frame can obtain was 
1 considered based on the plastic hinges forming in the vertical grouted cells. Proposed

2 model was verified by calculating the shear strength of database including walls tested by

3 authors and a good match was observed.

4

\section{Acknowledgments}

6 This project is supported by a grant from National Science Foundation (NSF) grant

7 No. 1208208. The support of Delaware Valley Masonry Institute and Sabia Mason

8 Contractors in providing the mason to build the test specimens is acknowledged. The

9 results, opinions, and conclusions expressed in this paper are solely those of the authors

10 and do not necessarily reflect those of the sponsoring organizations.

11

\section{Abbreviation}

13 ACI

14 AS

15 ATC

16 CSA

17 FEMA

18 MSJC

19 NEHRP

$20 \quad$ NZS

21 TCCMAR

22 UBC
American Concrete Institute

Australian Standard;

Applied Technology Council;

Canadian Standards Association;

Federal Emergency Management Agency;

Masonry Standards Joint Committee;

National Earthquake Hazards Reduction Program;

New Zealand Standard;

Technical Coordinating Committee for Masonry Research; and Uniform Building Code. 


\section{$1 \quad$ Nomenclature}

2 The following symbols are used in this paper:

$3 \quad A_{\text {infill }}=$ area of a single infill panel, $\left(\mathrm{mm}^{2}\right)$;

$4 \quad A_{n}=$ net cross-sectional area, $\left(\mathrm{mm}^{2}\right)$;

$5 \quad A_{g}=$ gross cross-sectional area, $\left(\mathrm{mm}^{2}\right)$;

$6 \quad A_{h}=$ area of single horizontal reinforcing steel bar, $\left(\mathrm{mm}^{2}\right)$;

$7 \quad A_{n}=$ net cross-sectional area, $\left(\mathrm{mm}^{2}\right)$;

$8 \quad A_{\text {strut }}=$ net cross-sectional area of equivalent strut, $\left(\mathrm{mm}^{2}\right)$;

$9 \quad \mathrm{~A}_{\mathrm{v}}=$ area of longitudinal reinforcement, $\left(\mathrm{mm}^{2}\right)$;

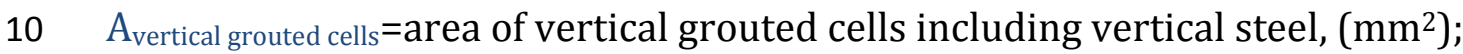

$11 \quad \mathrm{~A}_{\text {grouted cells }}=$ area of grouted cells without area of steel, $\left(\mathrm{mm}^{2}\right)$;

12 a=depth of compression stress block, $(\mathrm{mm})$;

$13 \mathrm{~b}_{\mathrm{w}}=$ wall width, $(\mathrm{mm})$;

$14 \mathrm{C}_{\mathrm{ap}}=$ coefficient to account the type of masonry used in construction;

15 d=distance from extreme compression fiber to centroid of longitudinal tension 16 reinforcement, or $0.8 \mathrm{~L}$ for walls, $(\mathrm{mm})$;

17 d'=distance between wall edge and outermost wall vertical reinforcing steel, (mm);

$18 \mathrm{~d}_{\mathrm{eff}}=$ effective depth of section, $(\mathrm{mm})$;

$19 \mathrm{~d}_{\mathrm{s}}=$ actual depth of a member in direction of shear considered, $(\mathrm{mm})$;

$20 \mathrm{~d}_{\mathrm{y}}=$ drift index of yielding point of displacement ductility curve;

$21 \mathrm{~d}_{\mathrm{u}}=$ ultimate drift index for displacement ductility curve;

$22 \mathrm{f}=$ diagonal force in equivalent strut, $(\mathrm{kN})$;

$23 \quad \mathrm{E}_{\text {steel }}=$ module of elasticity of steel, (MPa); 
$1 \quad E_{\text {grout }}=$ module of elasticity of concrete, (MPa);

$2 \mathrm{f}_{\mathrm{m}}=$ masonry compressive strength, (MPa);

$3 \mathrm{f}_{\mathrm{yh}}=$ yield strength of horizontal reinforcing steel, (MPa);

$4 \quad \mathrm{f}_{\mathrm{yv}}=$ yield strength of vertical reinforcing steel, (MPa);

$5 \mathrm{~h}=$ wall height, (mm);

$6 \mathrm{~h}_{\mathrm{u}}=$ masonry unit height, $(\mathrm{mm})$;

$7 \quad$ k=ductility reduction factor;

$8 \quad k_{p}=$ coefficient of the effect of flexural reinforcement;

$9 \quad \mathrm{k}_{\mathrm{u}}=$ reduction factor;

10 L=wall length, (mm);

$11 L_{d h}=$ development length of shear reinforcement, (mm);

$12 \quad \mathrm{M}_{\mathrm{p}}=$ plastic moment, (N.mm)

$13 \mathrm{M} / \mathrm{VL}=$ aspect ratio;

14 n=number of vertical grouted cells

$15 \mathrm{~N}^{*}=$ factored axial compression load, $(\mathrm{kN})$;

$16 \mathrm{P}=$ axial load, $(\mathrm{kN})$;

$17 \quad P_{\text {infill }}=$ axial load in the infill panel, $(\mathrm{kN})$;

$18 \mathrm{~S}_{\mathrm{h}}=$ spacing of horizontal shear reinforcement, (mm);

$19 t_{\text {eff }}=$ effective wall thickness, $(\mathrm{mm})$;

$20 V_{n}-A=$ shear strength provided by the first term of MSJC (2013), (kN);

$21 V_{n}-B=$ shear strength provided by the second term of MSJC (2013), (kN);

$22 \mathrm{~V}_{\mathrm{n}}-\mathrm{C}=$ shear strength provided by the third term of MSJC (2013), (kN);

$23 \quad V_{\text {exp }}=$ experimentally measured shear strength, $(\mathrm{kN})$; 
$1 V_{\text {frame }}=$ shear strength provided by grouted frame, $(\mathrm{kN})$;

$2 \mathrm{~V}_{\mathrm{i}}=$ initial shear strength, $(\mathrm{kN})$;

$3 \quad V_{\text {infill }}=$ shear strength provided by infill, $(\mathrm{kN})$;

$4 \quad V_{\mathrm{m}}=$ shear strength provided by masonry, $(\mathrm{kN})$;

$5 \quad V_{\mathrm{n}}=$ nominal shear strength, $(\mathrm{kN})$;

$6 \quad V_{p}=$ shear strength provided by axial load, $(\mathrm{kN})$;

$7 \quad \mathrm{~V}_{\mathrm{r}}=$ residual shear strength, $(\mathrm{kN})$;

$8 V_{s}=$ shear strength provided by shear reinforcement, $(\mathrm{kN})$;

$9 \quad \mathrm{~V}_{\mathrm{u}}=$ ultimate shear force, $(\mathrm{kN})$;

$10 \mathrm{~V}_{\mathrm{bm}}=$ basic shear stress provided by masonry, (MPa);

$11 \mathrm{~V}_{\mathrm{m}}=$ shear stress provided by masonry, (MPa);

$12 \mathrm{w}=$ unit width, $(\mathrm{mm})$;

$13 \mathrm{w}_{\mathrm{s}}=$ strut width, $(\mathrm{mm})$;

$14 \tau_{\mathrm{DT}}=$ shear stress of diagonal tension specimen, (MPa);

$15 v_{n}=$ total shear stress corresponding to $V_{n},(M P a)$;

$16 \quad U_{n(\max )}=$ maximum permitted total shear stress, (MPa);

$17 \quad v_{\mathrm{p}}=$ shear stress provided by axial compression stress, (MPa);

$18 v_{\mathrm{s}}=$ shear stress provided by shear reinforcement, (MPa);

$19 \alpha=$ angle formed between centers of load application and reaction;

$20 \gamma=$ factor concerning the type of grouting;

$21 \gamma_{\mathrm{g}}=$ factor for partially grouted walls;

$22 \delta$ =factor concerning loading method;

$23 \mu=$ coefficient of friction; 
$1 \quad \mu=$ ductility level;

$2 \mu_{\Delta}=$ displacement ductility;

$3 \quad \rho_{\mathrm{h}}=$ ratio of shear reinforcing steel;

$4 \rho_{\mathrm{v}}=$ ratio of vertical reinforcing steel;

$5 \quad \rho_{\mathrm{ve}}=$ ratio of outermost wall vertical reinforcing steel;

$6 \rho_{\mathrm{w}}=\sum \mathrm{A}_{\mathrm{v}} /\left(\mathrm{b}_{\mathrm{w}} \mathrm{d}\right) ;$ and

$7 \quad \sigma_{\mathrm{n}}=$ axial stress, $(\mathrm{MPa})$.

9 9. References

10 [1] Matsumura A. Shear strength of reinforced masonry walls. Proceedings of the 9th World Conference on Earthquake Engineering, Tokyo, 1988;7:121-126.

12 [2] Shing, P. B., Schuller, M., and Hoskere, V. S. In-plane resistance of reinforced masonry shear walls. Journal of Structural Engineering 1990;116(3), 619-639.

[3] Standard Association of New Zealand (SANZ). Code of practice for the design of masonry structures. NZS 4230:1990, Wellington, New Zealand, Parts 1 and 2.

[4] Anderson, D. L. and Priestley, M. J. N. In plane shear strength of masonry walls. Saskatoon, SK, Canada.

[5] NEHRP. NEHRP recommended provisions (FEMA 302) and commentary (FEMA 303) for seismic regulations for new buildings and other structures. Federal Emergency Management Agency (FEMA), Washington, DC; 1997.

[6] Uniform Building Code (UBC). International conference of building officials. Volume 2, Whittier, California, April 1997, 492p. 
[7] AS 3700. Code of practice for the use of masonry-Part 2: Structural use of reinforced and prestressed masonry. Standards Australia Ltd, Sydney; 2011.

[8] Standards Association of New Zealand (SANZ). Design of reinforced concrete masonry structures. NZS 4230:2004, Wellington, New Zealand; 2004.

[9] Canadian Standard Association S304.1-04. CSA. Design of masonry structures. Canadian Standards Association, Mississauga, Ontario, Canada; 2004.

[10] Voon, K. C. and Ingham, J. M. Experimental in-plane shear strength investigation of reinforced concrete masonry walls. Journal of Structural Engineering 2006;132(3), 400-408.

[11] Masonry Standards Joint Committee (MSJC). Building code requirements for masonry structures. TMS 402-08, ACI 530-08, and ASCE 5-08, The Masonry Institute, Boulder, American Concrete Institute, ASCE, Farmington Hills, MI, Reston, VA; 2008.

[12] Masonry Standards Joint Committee (MSJC). Building code requirements for masonry structures. TMS 402-13, ACI 530-13, and ASCE 5-13, The Masonry Institute, Boulder, American Concrete Institute, ASCE, Farmington Hills, MI, Reston, VA; 2013.

[13] TMS 402/602-16. Building code requirements and specifications for masonry structures, The Masonry Society, Longmont, Colorado, 2016.

[14] Noland, J. L. A review of the US coordinated program for masonry building research. Proceeding of 4th North American Masonry Conference, Los Angeles, California; 1987.

[15] Schultz, A. E. Seismic resistance of partially-grouted masonry shear walls. Worldwide Advances in Structural Concrete and Masonry, 1996a;211-222. American Society of Civil Engineers (ASCE). 
1 [16] Minaie, E., Mota, M., Moon, F. L., Hamid, A. A. In-plane behavior of partially grouted reinforced concrete masonry shear walls. Journal of Structural Engineering 2010;136(9):1089-1097.

[17] Bolhassani, M., Hamid, A. A., Lau, A. C., and Moon, F. L. Simplified micro modeling of partially grouted masonry assemblages. Construction and Building Materials $2015 ; 83,159-173$.

[18] Bolhassani, M., Hamid, A. A., and Moon, F. L. Enhancement of lateral in-plane capacity of partially grouted concrete masonry shear walls. Engineering Structures 2016; 108, 59-76.

[19] Bolhassani, M., Hamid, A. A., and Moon, F. L. Enhancement of seismic performance of partially grouted reinforced masonry shear walls. 10th US National Conference on Earthquake Engineering, 2014; 12-35.

[20] Bolhassani, M., Hamid, A., and Moon, F. L. Effect of axial load on the behavior of doubly reinforced partially grouted reinforced masonry shear walls. 12 North American Masonry Conference, Denver, Colorado; 17-21 May, 2015.

[21] Chen, S. W., Hidalgo, H. A., Mayes, L. R., Clough, R. W., and McNiven, H. M. Cyclic loading of masonry single piers, vol. 2-height to width ratio of 1 . Tech. Rep. UCB/EERC-78/28, University of California, Berkeley, CA; 1978.

[22] Matsumura, A. Shear strength of reinforced hollow unit masonry walls. Proceeding of 4th North American Masonry Conference, Los Angeles, California; 1987.

[23] Johal, L. S. P., and Anderson, E. D. Shear strength of masonry piers under cyclic loading. Masonry: Materials, Design, Construction, and Maintenance 1988; 992:18. 
1 [24] Yancey, C. W. C., and Scribner, C. F. Influence of horizontal reinforcement on shear resistance of concrete block masonry walls. Tech. Rep. NISTIR 4202, National Institute of Standards and Technology, Gaithersburg, MD; 1989.

[25] Brammer, D. R. The lateral force-deflection behavior of nominally reinforced concrete masonry walls. Master's thesis, University of Auckland, Auckland; 1995.

[26] Voon, K. C. In-plane seismic design of concrete masonry structures. Ph.D. thesis, University of Auckland, Auckland; 2007.

[27] Elmapruk, J. H. Shear strength of partially grouted squat masonry shear walls. Master's thesis, Washington State University, Pullman, WA; 2010.

[28] Nolph, S. M., \& ElGawady, M. A. Static cyclic response of partially grouted masonry shear walls. Journal of structural engineering 2011;138(7), 864-879.

[29] Sveinsson, B. I., McNiven, H. D., and Sucuoglu, H. Cyclic loading tests of masonry single piers, vol 4-additional tests width height to width ratio of 1 . Tech. Rep. UCB/EERC85/15, University of California, Berkeley, CA; 1985.

[30] Davis, C. L. Evaluation of design provisions for in-plane shear in masonry walls. Master's thesis, Washington State University, Pullman, WA; 2008.

[31] ElGawady, M. A. Shear strength equations for partially grouted masonry walls. 12th North American Masonry Conference, Denver, Colorado; May 17-20, 2015.

[32] Ingham, J. L., Davidson, B., Brammer, D., Voon, K. C. Testing and codification of partially grout-filled nominally-reinforced concrete masonry subjected to in-plane cyclic loads. The Masonry Society Journal 2001;19(1):83-96. 
1 [33] Johnson, C. A., and Schultz A. E. Simulated seismic testing of partially-grouted masonry sub-assemblages. 10th US National Conference on Earthquake Engineering, 2014; 21-25.

[34] ElGawady, M. A., and Elmapruk, J. H. Experimental shear strength of squat masonry shear walls. 8th Int. Conference on Urban Earthquake Engineering, Tokyo; March 78, 2011.

[35] Hamid, A. A., Bolhassani, M., Turner, A., Minaie, E., Moon, F. L. Mechanical properties of ungrouted and grouted concrete masonry assemblages. 12th Canadian Masonry Symposium, Vancouver, British Columbia; 2013.

[36] ElDakhakhni, W. W. Nonlinear finite-element modeling of concrete masonry-infilled steel frame. MSc thesis, Drexel Univ., Philadelphia; 2000.

[37] Manual, A. U. S. Ansys Inc. Cannonsburg, PA; 2015.

[38] Abaqus. Abaqus 6.14-AP. Dassault Systemes Simulia Corp., 2014, Providence, RI.

[39] ASTM. Standard test method for diagonal tension (shear) in masonry assemblages. E 519-81, West Conshohocken, PA; 2010.

[40] Polyakov, S. V. Masonry in framed buildings. Godsudarstvenoe Isdatel' stvo Literatury Po Stroidal stvui Architecture, Moscow; 1956.

[41] Stafford-Smith, B., and Carter, C. Method of analysis for infilled frames. Proc. Inst. Civ. Eng., Struct. Build., 1969;44, 31-48.

[42] Saneinejad, A., and Hobbs, B. Inelastic design of infilled frames. J. Struct. Eng. $1995 ; 121(4), 634-650$.

[43] Nateghi-Alahi, F., and Khazaei-Poul, M. Analytical study on the strengthened steel plate shear walls by FRP laminate. Procedia Engineering 54 (2013): 377-386. 
1 [44] Nateghi-Alahi, F., and Khazaei-Poul, M. Experimental study of steel plate shear walls with infill plates strengthened by GFRP laminates. Journal of Constructional Steel Research

3 78 (2012): 159-172.

4 [45] ACI 318. Building code requirements for structural concrete (ACI 318-02) and commentary (ACI 318R-02). American Concrete Institute (ACI), Farmington Hills, MI; 2011. 